Check for updates

Cite this: RSC Adv., 2017, 7, 23432

Received 20th March 2017

Accepted 20th April 2017

DOI: $10.1039 / c 7 r a 03268 d$

rsc.li/rsc-advances

\title{
A series of five-coordinated copper coordination polymers for efficient degradation of organic dyes under visible light irradiation $\dagger$
}

\begin{abstract}
Lu-Lu Shi, Tian-Rui Zheng, Min Li, Lin-Lu Qian, Bao-Long Li (D) and Hai-Yan Li
The copper(II) coordination polymers $\left\{\left[\mathrm{Cu}_{4}(\mathrm{OH})_{2}(\text { bix })_{2}(1,2,4-\text { btc })_{2}\left(\mathrm{H}_{2} \mathrm{O}\right)_{2}\right] \cdot 3 \mathrm{H}_{2} \mathrm{O}\right\}_{n}$ (1), $\left[\mathrm{Cu}_{2}(\mathrm{bix})(\mathrm{ip})_{2}\right]_{n}$ (2), $\left[\mathrm{Cu}_{2}(\text { bix })(\text { Meip })_{2}\right]_{n}$ (3), $\left\{\left[\mathrm{Cu}_{2}(\text { bix })(\text { pbda })_{2}\right] \cdot \mathrm{H}_{2} \mathrm{O}\right\}_{n}$ (4) and $\left\{\left[\mathrm{Cu}_{2}(\text { bix })_{1.5}(2,5-\text { pydc })_{2}\left(\mathrm{H}_{2} \mathrm{O}\right)\right] \cdot 2 \mathrm{H}_{2} \mathrm{O}\right\}_{n}$ (5) were synthesized using the hydrothermal method (bix = 1,4-bis(2-methyl-imidazol-1-ylmethyl)benzene, 1,2,4btc $=1,2,4$-benzenetricarboxylate, ip $=$ isophthalate, Meip $=5$-methyl-isophthalate, pbda $=1,4$ benzenediacatate, 2,5-pydc $=2,5$-pyridine-dicarboxylate). 1 exhibits a $(3,5)$-connected 2D network with the point symbol of $\left(4^{2} \cdot 6\right)\left(4^{2} \cdot 6^{7} \cdot 8\right)$ based on the $\left[\mathrm{Cu}_{2}(\mu-\mathrm{OH})\right]$ dimer. 2 exhibits the 2 -fold interpenetrating three-dimensional pcu network based on the $\left[\mathrm{Cu}_{2}(\mathrm{COO})_{4}\right]$ dimers. 3 exhibits the 2-fold interpenetrating three-dimensional pcu network based on the $\left[\mathrm{Cu}_{2}(\mathrm{COO})_{2}\right]$ and $\left[\mathrm{Cu}_{2}(\mathrm{COO})_{4}\right]$ dimers. 4 shows an unusual 6 -connected self-catenated 3D network with the point symbol of $\left(4^{4} \cdot 6^{10} \cdot 8\right)$ based on $\left[\mathrm{Cu}_{2}(\mathrm{COO})_{4}\right]$ dimers. 5 exhibits a $(3,4)$-connected $2 \mathrm{D}$ network with the point symbol of $\left(4^{2} \cdot 6\right)\left(4^{2} \cdot 6^{3} \cdot 8\right)$. 1-5 are semiconducting in nature, with $E_{\mathrm{g}}$ of $2.21 \mathrm{eV}(1), 2.35 \mathrm{eV}(2), 2.41 \mathrm{eV}$ (3), $2.13 \mathrm{eV}$ (4), and $2.62 \mathrm{eV}$ (5). 1-5 are highly efficient and universal photocatalysts for the degradation of the organic dyes methylene blue $(\mathrm{MB})$, rhodamine $\mathrm{B}(\mathrm{RhB})$ and methyl orange $(\mathrm{MO})$ under visible light irradiation, and are very stable and easily separated from the reaction system for reuse. This work shows that the coordinated unsaturated copper coordination polymers should be very promising photocatalysts for degradation of organic dyes.
\end{abstract}

\section{Introduction}

Today, water pollution has become a serious global environmental problem facing humans worldwide with the development of modern industry. ${ }^{1}$ In particular, the organic dyes released into water from dyeing, dyestuffs and the textile industry are the main contamination of wastewater. Photocatalytic degradation of organic pollutants is an effective technique to eliminate organic pollutants. Traditional semiconductors such as metal oxides $\mathrm{TiO}_{2}, \mathrm{ZnO}$, metal sulfides and composites are usually employed as photocatalysts for photocatalytic degradation of organic dyes. ${ }^{2}$ However, the high band gaps $\left(E_{\mathrm{g}}\right)$ of these semiconductors (usually above $3 \mathrm{eV}, 3.2 \mathrm{eV}$ for $\mathrm{TiO}_{2}, 3.4 \mathrm{eV}$ for $\mathrm{ZnO}$ ), make them only absorb a small amount of ultraviolet light from sunlight. ${ }^{3}$ The composite semiconductors such as doping the metal ions, or coupling metal oxides (for example $\mathrm{TiO}_{2}$ ) with other semiconductors with suitable electronic band (such as $\mathrm{Cu}_{x} \mathrm{~S}, \mathrm{CuInS}_{2}$,

State and Local Joint Engineering Laboratory for Functional Polymeric Materials, College of Chemistry, Chemical Engineering and Materials Science, Soochow University, Suzhou 215123, PR China. E-mail: libaolong@suda.edu.cn

$\dagger$ Electronic supplementary information (ESI) available: Selected bond lengths and angles, hydrogen bond and additional figures for the crystal structures, XRD patterns, the UV-visible spectra, catalysts recycling, X-ray crystallographic file in CIF format. CCDC 1538437-1538441. For ESI and crystallographic data in CIF or other electronic format see DOI: $10.1039 / \mathrm{c} 7 \mathrm{ra03268d}$
$\mathrm{ZnO}, \mathrm{SnO}_{2}$ ) are useful strategy for developing semiconductor composite photocatalysts under visible light or sunlight irradiation. ${ }^{4}$ Therefore, apart from the developing the composite semiconductor photocatalysts, searching and development of the efficient and environment friendly new photocatalysts under visible light or sunlight irradiation is very important.

In the last two decades, coordination polymers have attracted great interest in inorganic chemistry and materials science because of their fascinating topologies and interesting properties for potential applications as functional materials. ${ }^{5,6}$ Coordination interactions between metal and ligand result in different metal-ligand charge transfers and affect bandgap width of coordination polymers. Coordination polymers with high or narrow band gaps can absorb UV or visible light as photocatalysts. Recent researches show that these coordination polymers are quite effective photocatalysts for the degradation of organic dyes under UV or even visible light irradiation. ${ }^{7-14}$ But relative few coordination polymers exhibit effective photocatalytic activity under visible light irradiation due to most of coordination polymers with poor photoresponse in the visible region. ${ }^{10-14}$ Therefore, the designation and synthesis of coordination polymers with narrow band gaps is very promising prospect in developing efficient visible light photocatalysts.

Copper, as an abundant and cheap element, has been widely studied since the beginning of chemistry. Copper salt and its 
coordination polymers are good catalysts for catalytic organic reactions and degradation of organic pollutants. ${ }^{14-17}$ For example, a semi-conductive copper framework $\left\{\left[\mathrm{Cu}^{\mathrm{I}} \mathrm{Cu}^{\mathrm{II}} 2^{-}\right.\right.$ $\left.\left.(\mathrm{DCTP})_{2}\right] \mathrm{NO}_{3} \cdot 1.5 \mathrm{DMF}\right\}_{n} \quad$ (DCTP $=4^{\prime}$-(3,5-dicarboxyphenyl)$4,2^{\prime}: 6^{\prime}, 4^{\prime \prime}$-terpyridine) demonstrated hydrogen production in the presence of $\mathrm{Pt}$ co-catalyst and the degradation of methylene blue. ${ }^{15}$ Up to now, most coordination polymers show selective photocatalytic degradation of one organic dye. ${ }^{7-12}$ Few coordination polymers can photocatalytic degradation of two organic dyes. ${ }^{13}$ Universal and highly efficient photocatalysts are rare. ${ }^{\mathbf{1 4}}$

In previous work, we synthesized many coordination polymers with unusual topologies and interesting properties. ${ }^{17,18}$ Some copper coordination polymers show good photocatalytic activity in the degradation of organic dyes under UV irradiation. ${ }^{17}$ For examples, $\left\{\left[\mathrm{Cu}(\mathrm{tmtz})\left(\mathrm{H}_{2} \mathrm{O}\right)_{4}\right]\left[\mathrm{Cu}_{2}(\mathrm{tmtz})_{2}(\mathrm{sip})_{2}\right] \cdot 4 \mathrm{H}_{2} \mathrm{O}\right\}_{n}(\mathrm{tmtz}=$ 1,4-bis(1,2,4-triazol-1-ylmethyl)-2,3,4,5-tetramethylbenzene, $\operatorname{sip}=$ 5 -sulfoisophthalate) exhibits good photocatalytic activity for the degradation of methyl orange. ${ }^{17 a}\left[\mathrm{Cu}_{4}(\mathrm{OH})_{2} \text { (btre)(1,2,3-btc }\right)_{2}$ $\left.\left.\left(\mathrm{H}_{2} \mathrm{O}\right)_{2}\right] \cdot 2 \mathrm{H}_{2} \mathrm{O}\right\}_{n}$ (btre = 1,2-bis(1,2,4-triazol-4-yl)ethane, 1,2,3btc $=1,2,3$-benzenetricarboxylate) presents the good photocatalytic activity for the degradation of methyl orange. ${ }^{17 b}$ $\left\{\left[\mathrm{Cu}_{4}(\mathrm{OH})_{2}(\mathrm{itp})_{2}(\mathrm{btc})_{2}\left(\mathrm{H}_{2} \mathrm{O}\right)_{4}\right]\left[\mathrm{Cu}\left(\mathrm{H}_{2} \mathrm{O}\right)_{4}(\mathrm{Hbtc}]_{2} \cdot 4 \mathrm{H}_{2} \mathrm{O}\right\}_{n}, \quad\left\{\left[\mathrm{Cu}_{4}{ }^{-}\right.\right.\right.$ $\left.\left.(\mathrm{OH})_{2}(\mathrm{itp})_{2}(\mathrm{btc})_{2}\right] \cdot 2 \mathrm{EtOH} \cdot 2 \mathrm{H}_{2} \mathrm{O}\right\}_{n}$ and $\left\{\left[\mathrm{Cu}_{4}(\mathrm{OH})_{2}(\mathrm{itp})_{2}(\operatorname{sip})_{2}\left(\mathrm{H}_{2}-\right.\right.\right.$ $\left.\left.\mathrm{O})_{4}\right] \cdot 4 \mathrm{H}_{2} \mathrm{O}\right\}_{n}$ (btc = 1,2,3-benzenetricarboxylate, itp = 1-imidazol1-yl-3-(1,2,4-triazol-4-yl)propane) can act as universal and highly efficient photocatalysts for the degradation of organic dyes such as methyl orange (MO), methylene blue (MB) and rhodamine $\mathrm{B}$ (RhB). ${ }^{17 c}$

In the present work, in our effort to obtain effective visible light photocatalysts properties, we synthesized five intriguing copper(II) coordination polymers $\left\{\left[\mathrm{Cu}_{4}(\mathrm{OH})_{2}(\mathrm{bix})_{2}(1,2,4 \text {-btc })_{2}\left(\mathrm{H}_{2} \mathrm{O}\right)_{2}\right] \cdot 3 \mathrm{H}_{2} \mathrm{O}\right\}_{n}$ (1), $\left[\mathrm{Cu}_{2}(\text { bix })(\mathrm{ip})_{2}\right]_{n}$ (2), $\left[\mathrm{Cu}_{2}(\text { bix })(\mathrm{Meip})_{2}\right]_{n}$ (3), $\left\{\left[\mathrm{Cu}_{2}(\right.\right.$ bix $\left.)(\text { pbda })_{2}\right]$. $\left.\mathrm{H}_{2} \mathrm{O}\right\}_{n}$ (4) and $\left\{\left[\mathrm{Cu}_{2}(\text { bix })_{1.5}(2,5-\text { pydc })_{2}\left(\mathrm{H}_{2} \mathrm{O}\right)\right] \cdot 2 \mathrm{H}_{2} \mathrm{O}\right\}_{n}$ (5) using the hydrothermal method (bix $=$ 1,4-bis(2-methyl-imidazol-1ylmethyl)benzene, 1,2,4-btc $=1,2,4$-benzenetricarboxylate, ip = isophthalate, Meip = 5-methyl-isophthalate, pbda $=$ 1,4-benzenediacatate, 2,5-pydc $=$ 2,5-pyridine-dicarboxylate). 1-5 exhibit diverse structures. 1-5 are highly efficient and universal photocatalysts for the degradation of the organic dyes methyl orange (MO), methylene blue (MB) and rhodamine $\mathrm{B}(\mathrm{RhB})$ under visible light irradiation.

\section{Experimental section}

\section{Materials and physical measurements}

1,4-Bis(2-methyl-imidazol-1-ylmethyl)benzene (bix) was synthesized according the literature method. ${ }^{19}$ All reagents were of analytical grade and used without further purification. Elemental analyses for $\mathrm{C}, \mathrm{H}$ and $\mathrm{N}$ were performed on a PerkinElmer 240C analyser. IR spectra were obtained for $\mathrm{KBr}$ pellets on a Nicolet 170SX FT-IR spectrophotometer in the 4000-400 $\mathrm{cm}^{-1}$ region. XPRD were performed on a D/MAX-3C diffractometer with the $\mathrm{Cu} \mathrm{K}_{\alpha}$ radiation $(\lambda=1.5406 \AA)$ at room temperature.

Synthesis of $\left\{\left[\mathrm{Cu}_{4}(\mathrm{OH})_{2}(\mathrm{bix})_{2}(1,2,4-b t c)_{2}\left(\mathrm{H}_{2} \mathrm{O}\right)_{2}\right] \cdot 3 \mathrm{H}_{2} \mathrm{O}\right\}_{n}(1)$. A mixture of bix $(0.1 \mathrm{mmol}), 1,2,4-\mathrm{H}_{3}$ btc $(0.1 \mathrm{mmol})$, $\mathrm{Cu}\left(\mathrm{NO}_{3}\right)_{2} \cdot 3 \mathrm{H}_{2} \mathrm{O}(0.4 \mathrm{mmol}), \mathrm{NaOH}(0.3 \mathrm{mmol})$ and $15 \mathrm{~mL} \mathrm{H}_{2} \mathrm{O}$ was placed in a Teflon-lined stainless steel vessel, heated to $110{ }^{\circ} \mathrm{C}$ for seven days, then cooled to room temperature over $24 \mathrm{~h}$. The blue crystals of 1 were obtained. Anal. calcd for $\mathrm{C}_{50} \mathrm{H}_{54} \mathrm{Cu}_{4} \mathrm{~N}_{8} \mathrm{O}_{19}$ (1): C, 45.32; H, 4.11; N, 8.46; found: C, 45.14; H, 4.06; N, 8.37\%. IR ( $\left.\mathrm{cm}^{-1}, \mathrm{KBr}\right): 3378 \mathrm{~m}, 1616 \mathrm{~s}, 1583 \mathrm{~s}, 1551$ m, 1508 w, 1486 w, 1423 m, 1379 s, 1354 m, 1285 w, 1162 w, 1145 w, 1009 w, 826 w, 777 m, 731 w, 670 w, 584 w, 532 w.

Synthesis of $\left[\mathrm{Cu}_{2}(\mathrm{bix})(\mathrm{ip})_{2}\right]_{\boldsymbol{n}}$ (2). A mixture of bix $(0.1 \mathrm{mmol})$, $\mathrm{H}_{2}$ ip $(0.2 \mathrm{mmol}), \mathrm{Cu}\left(\mathrm{NO}_{3}\right)_{2} \cdot 3 \mathrm{H}_{2} \mathrm{O}(0.4 \mathrm{mmol}), \mathrm{NaOH}(0.4 \mathrm{mmol})$ and $15 \mathrm{~mL} \mathrm{H}_{2} \mathrm{O} / \mathrm{EtOH}(1: 1, \mathrm{v} / \mathrm{v})$ was placed in a Teflon-lined stainless steel vessel, heated to $70{ }^{\circ} \mathrm{C}$ for five days, then cooled to room temperature over $12 \mathrm{~h}$. The blue crystals of 2 were obtained. Anal. calcd for $\mathrm{C}_{32} \mathrm{H}_{26} \mathrm{Cu}_{2} \mathrm{~N}_{4} \mathrm{O}_{8}$ (2): C, 53.26; $\mathrm{H}$, 3.63; N, 7.77; found: C, 53.14; H, 3.60; N, 7.73\%. IR ( $\left.\mathrm{cm}^{-1}, \mathrm{KBr}\right)$ : 3443 m, 1629 s, 1576 w, 1540 w, 1506 w, 1396 s, 1384 s, 1277 w, 1161 w, 1133 w, 1083 w, 1000 w, 848 w, 803 w, 760 w, 742 m, $718 \mathrm{~s}, 666 \mathrm{w}, 475 \mathrm{w}$.

Synthesis of $\left[\mathrm{Cu}_{2}(\text { bix })(\text { Meip })_{2}\right]_{\boldsymbol{n}}$ (3). A mixture of bix (0.1 $\mathrm{mmol}), \mathrm{H}_{2}$ Meip (0.2 mmol), $\mathrm{Cu}\left(\mathrm{NO}_{3}\right)_{2} \cdot 3 \mathrm{H}_{2} \mathrm{O}(0.4 \mathrm{mmol}), \mathrm{NaOH}$ ( $0.4 \mathrm{mmol}$ ) and $15 \mathrm{~mL} \mathrm{H}_{2} \mathrm{O}$ was placed in a Teflon-lined stainless steel vessel, heated to $110{ }^{\circ} \mathrm{C}$ for five days, then cooled to room temperature over $24 \mathrm{~h}$. The green crystals of 3 were obtained. Anal. calcd for $\mathrm{C}_{34} \mathrm{H}_{30} \mathrm{Cu}_{2} \mathrm{~N}_{4} \mathrm{O}_{8}$ (3): C, 54.47; H, 4.03; N, 7.47; found: C, 54.34; H, 3.99; N, 7.43\%. IR ( $\left.\mathrm{cm}^{-1}, \mathrm{KBr}\right): 1633 \mathrm{~s}, 1582$ m, 1508 w, 1481 w, 1447 w, 1424 m, 1366 s, 1298 w, 1285 w, 1170 w, 1139 w, 849 w, 774 m, 735 m, 681 w, 472 w.

Synthesis of $\left\{\left[\mathrm{Cu}_{2}(\text { bix })(\text { pbda })_{2}\right] \cdot \mathbf{H}_{2} \mathrm{O}\right\}_{n}$ (4). A mixture of bix (0.1 mmol), $\mathrm{H}_{2}$ pbda $(0.2 \mathrm{mmol}), \mathrm{Cu}\left(\mathrm{NO}_{3}\right)_{2} \cdot 3 \mathrm{H}_{2} \mathrm{O}(0.4 \mathrm{mmol})$, $\mathrm{NaOH}(0.4 \mathrm{mmol})$ and $15 \mathrm{~mL} \mathrm{H}_{2} \mathrm{O}$ was placed in a Teflon-lined stainless steel vessel, heated to $70{ }^{\circ} \mathrm{C}$ for two days, then cooled to room temperature over $12 \mathrm{~h}$. The green crystals of 4 were obtained. Anal. calcd for $\mathrm{C}_{36} \mathrm{H}_{34} \mathrm{Cu}_{2} \mathrm{~N}_{4} \mathrm{O}_{9}$ (4): C, 54.48; H, 4.32; N, 7.06; found: C, 54.41; H, 4.26; N, 7.03\%. IR $\left(\mathrm{cm}^{-1}, \mathrm{KBr}\right): 3443 \mathrm{~m}, 1625 \mathrm{~s}, 1516 \mathrm{w}, 1432 \mathrm{~m}, 1401 \mathrm{~s}, 1308 \mathrm{w}, 1209$ w, $1143 \mathrm{w}, 1001 \mathrm{w}, 752 \mathrm{w}, 732 \mathrm{w}, 719 \mathrm{~m}, 674 \mathrm{w}, 600 \mathrm{w}, 483 \mathrm{w}$.

Synthesis of $\left\{\left[\mathrm{Cu}_{2}(\mathrm{bix})_{1.5}(2,5-p y d c)_{2}\left(\mathrm{H}_{2} \mathrm{O}\right)\right] \cdot 2 \mathrm{H}_{2} \mathrm{O}\right\}_{n}$ (5). A mixture of bix $(0.15 \mathrm{mmol}), \mathrm{H}_{2}$ pbda $(0.2 \mathrm{mmol}), \mathrm{Cu}\left(\mathrm{NO}_{3}\right)_{2} \cdot 3 \mathrm{H}_{2} \mathrm{O}$ $(0.4 \mathrm{mmol}), \mathrm{NaOH}(0.4 \mathrm{mmol})$ and $15 \mathrm{~mL} \mathrm{H}_{2} \mathrm{O}$ was placed in a Teflon-lined stainless steel vessel, heated to $70{ }^{\circ} \mathrm{C}$ for three days, then cooled to room temperature over $12 \mathrm{~h}$. The blue crystals of 5 were obtained. Anal. calcd for $\mathrm{C}_{38} \mathrm{H}_{39} \mathrm{Cu}_{2} \mathrm{~N}_{8} \mathrm{O}_{11}(5)$ : C, 50.11; H, 4.32; N, 12.30; found: C, 49.96; H, 4.28; N, 12.23\%. IR (cm $\left.{ }^{-1}, \mathrm{KBr}\right): 3432 \mathrm{~m}, 3119 \mathrm{w}, 1654 \mathrm{~s}, 1628 \mathrm{~s}, 1505 \mathrm{w}, 1422 \mathrm{w}, 1384$ m, 1348 s, 1280 m, 1041 w, 827 w, 771 m, 749 w, 675 w, 545 w.

\section{Crystal data collection and refinement}

Suitable single crystals of 1-5 were carefully selected under an optical microscope and glued to thin glass fibers. The diffraction data were collected on Agilent Gemini Atlas CCD diffractometer with graphite monochromated $\mathrm{Cu} \mathrm{K}_{\alpha}$ radiation. Intensities were collected by the $\omega$ scan technique. The structures were solved by direct methods and refined with full-matrix least-squares technique (SHELXTL-97). ${ }^{20}$ The parameters of the crystal data collection and refinement of 1-5 are given in Table S1 (ESI $\dagger$ ). Selected bond lengths and bond angles are listed in Table S2 (ESI $\dagger$ ). 


\section{Photocatalytic reaction measurement}

The experiment was carried out a PCR-I multipurpose photoreactor (Beijing China Education Au-Light Company Limited, China) equipped a CEL-HXF300 Xe lamp with UV cut-off filter (providing visible light with $\lambda>400 \mathrm{~nm}$ ), which contains a cylindrical reactor (inner diameter $4.5 \mathrm{~cm}$ ) surrounded by a circulating water jacket to cool the reactor $\left(20^{\circ} \mathrm{C}\right)$, in a $40 \mathrm{~cm}$ $\times 40 \mathrm{~cm} \times 50 \mathrm{~cm}$ closed metal-box. 1 (40 mg), 2 (40 mg), 3 (40 $\mathrm{mg}), 4(40 \mathrm{mg})$ or $5(40 \mathrm{mg})$ and $0.50 \mathrm{~mL} 30 \% \mathrm{H}_{2} \mathrm{O}_{2}$ were added into $100 \mathrm{~mL}$ of a methyl orange (MO) solution $\left(10 \mathrm{mg} \mathrm{L}^{-1}\right)$, or methylene blue $(\mathrm{MB})$ solution $\left(10 \mathrm{mg} \mathrm{L}^{-1}\right)$, or rhodamine $\mathrm{B}$ (RhB) solution $\left(10 \mathrm{mg} \mathrm{L}^{-1}\right)$. The suspension solution was stirred in the dark for about $30 \mathrm{~min}$. Then, the mixture was stirred continuously under visible light irradiation from the lamp at a distance of $28 \mathrm{~cm}$ between the liquid surface and the cut-off filter. The light intensity of the liquid surface was $3850 \mathrm{~W}$ $\mathrm{m}^{-2}$ which was determined by PL-MW2000 photoradiometer (Beijing Perfect Light Company Limited). At a given interval, aliquots of the reaction mixture were periodically taken and analyzed with a UV-vis spectrophotometer at an absorption wavelength of $465 \mathrm{~nm}$ for MO, $664 \mathrm{~nm}$ for MB and $552 \mathrm{~nm}$ for RhB. The blank experiment and the control experiment with photocatalysts 1-5 in the absence of $\mathrm{H}_{2} \mathrm{O}_{2}$ were performed.

\section{Results and discussion}

\section{Crystal structure of $\left\{\left[\mathrm{Cu}_{4}(\mathrm{OH})_{2}(\mathrm{bix})_{2}(1,2,4-\mathrm{btc})_{2}\left(\mathrm{H}_{2} \mathrm{O}\right)_{2}\right]\right.$. $\left.3 \mathrm{H}_{2} \mathrm{O}\right\}_{n}$ (1)}

1 exhibits a $(3,5)$-connected $2 \mathrm{D}$ network based on the $\left[\mathrm{Cu}_{2}(\mu-\right.$ $\mathrm{OH})$ dimer. The asymmetric unit of $\mathbf{1}$ consists of two $\mathrm{Cu}$ (II) atoms, one bix, one 1,2,4-btc, one $\mu-\mathrm{OH}$, one coordinated water and disordered lattice water molecules. The $\mathrm{Cu} 1$ atom is fourcoordinated with two carboxylate oxygen atoms from two 1,2,4-btc (O1A, O3B), one $\mu-\mathrm{OH}$ oxygen atom (O7) and one imidazole nitrogen atoms from one bix (N1) in the distorted square geometry. The $\mathrm{Cu} 2$ atom is five-coordinated with two carboxylate oxygen atoms from two 1,2,4-btc (O2A, O5), one $\mu$ $\mathrm{OH}$ oxygen atom $(\mathrm{O} 7)$ and one imidazole nitrogen atoms from one bix (N3C) in the equation plane and one water oxygen atom (O8) in the apical position in the distorted square-pyramidal configuration (Fig. 1a). The structural distortion index $\tau$ for $\mathrm{Cu} 2$ atom is 0.202 , indicating that the coordination environment of the metal atom is closer to square-pyramidal geometry than trigonal-bipyramidal configuration. ${ }^{21}$

One carboxylate group (O1O2) of the 1,2,4-btc ligand exhibits bidentate bridging mode and connects two $\mathrm{Cu}(\mathrm{II})$ atoms (Cu1D, $\mathrm{Cu} 2 \mathrm{D})$. Two other carboxylate groups (O3O4, O5O6) show the monodentate mode and coordinate one $\mathrm{Cu}$ (II) atom (Cu1B or $\mathrm{Cu} 2$ ). Each 1,2,4-btc ligand links four $\mathrm{Cu}$ (II) atoms (Fig. S1 in $\mathrm{ESI} \dagger$ ). The $\mu-\mathrm{OH}$ oxygen atom (O7) connects two $\mathrm{Cu}(\mathrm{II})$ atoms and form $\left[\mathrm{Cu}_{2}(\mu-\mathrm{OH})\right]$ dimer. The $\left[\mathrm{Cu}_{2}(\mu-\mathrm{OH})\right]$ dimers are connected by 1,2,4-btc ligands and extend to form the onedimensional "ladder-like" chain (Fig. 1b).

The bix ligand shows the anti-conformation and bridges two $\mathrm{Cu}(\mathrm{II})$ atoms. The one-dimensional "ladder-like" chains are further joined by bix ligands to construct an unusual two-dimensional (a)

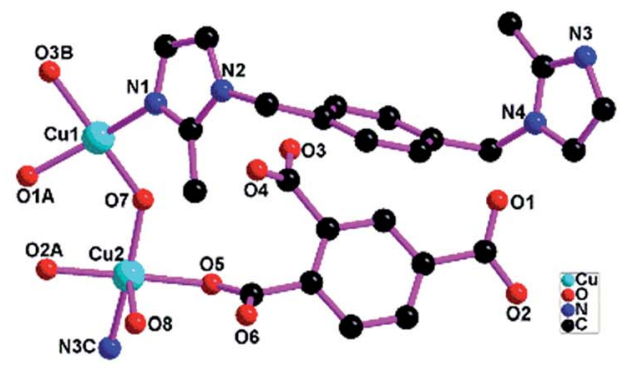

(b)

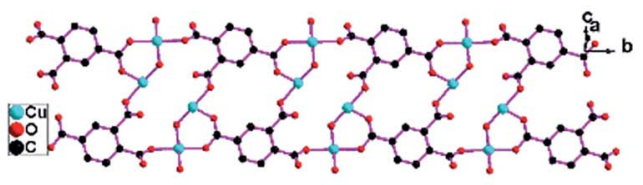

(c)

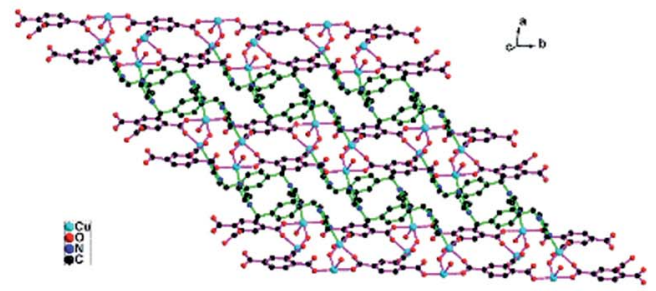

(d)

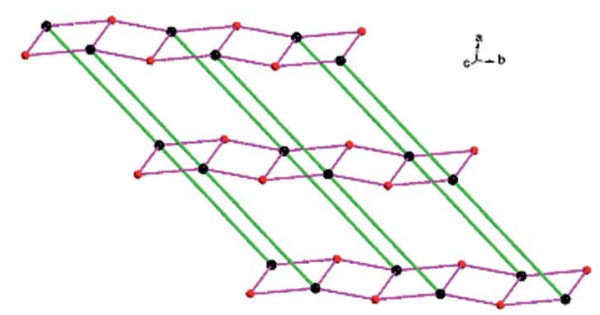

Fig. 1 (a) The coordination environment of the $\mathrm{Cu}(॥)$ atoms in 1; (b) the one-dimensional "ladder-like" chain $\left[\mathrm{Cu}_{2}(\mathrm{OH})(1,2,4-\mathrm{btc})\left(\mathrm{H}_{2} \mathrm{O}\right)\right]_{n}$ in 1; (c) the 2D network in 1; (d) the $(3,5)$-connected 2D network in 1 . The red and black balls exhibit the 3-connected 1,2,4-btc ligands and 5connected $\left[\mathrm{Cu}_{2}(\mathrm{OH})\right]$ units, respectively. Bright green sticks exhibit the bix ligands.

network (Fig. 1c). The topological analysis of $\mathbf{1}$ has been performed. If the $\left[\mathrm{Cu}_{2}(\mu-\mathrm{OH})\right]$ dimer is simplified as one node, the $\left[\mathrm{Cu}_{2}(\mu-\mathrm{OH})\right]$ dimers are 5 -connected because each $\left[\mathrm{Cu}_{2}(\mu-\mathrm{OH})\right]$ dimer connects three 1,2,4-btc and two bix ligands. The 1,2,4-btc ligands are 3-connected. The bix ligands are 2-connected. The twodimensional network can be simplified as a $(3,5)$-connected network (Fig. 1d) with the point symbol of $\left(4^{2} \cdot 6\right)\left(4^{2} \cdot 6^{7} \cdot 8\right) .{ }^{22}$ The three-dimensional supermolecular architecture (Fig. S2 in ESI $\dagger$ ) is formed through the hydrogen bond interactions between the

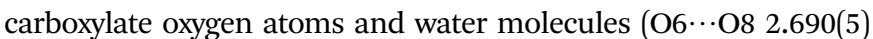

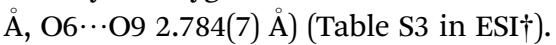

\section{Crystal structure of $\left[\mathrm{Cu}_{2}(\mathrm{bix})(\mathrm{ip})_{2}\right]_{n}(2)$}

2 exhibits the 2 -fold interpenetrating three-dimensional pcu network based on the $\left[\mathrm{Cu}_{2}(\mathrm{COO})_{4}\right]$ dimers. The asymmetric unit of 2 consists of two $\mathrm{Cu}$ (II) atoms ( $\mathrm{Cu} 1, \mathrm{Cu} 2)$, two halves bix (N1N2, N3N4) and two ip ligands (O1-O4, O5-O8). The Cu1 atom is coordinated by four carboxylate oxygen atoms from four ip ligands $(\mathrm{O} 1, \mathrm{O} 5, \mathrm{O} 2 \mathrm{~A}, \mathrm{O} 6 \mathrm{~A})$ in the equation positions and one 
(a)

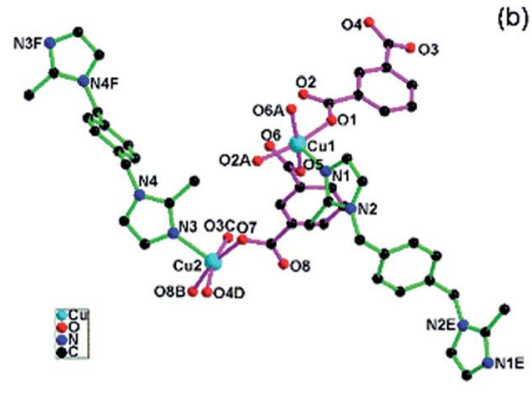

(b)

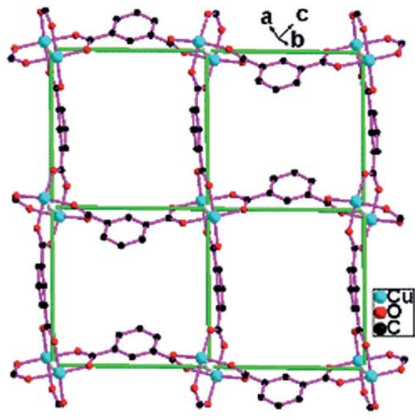

(c)

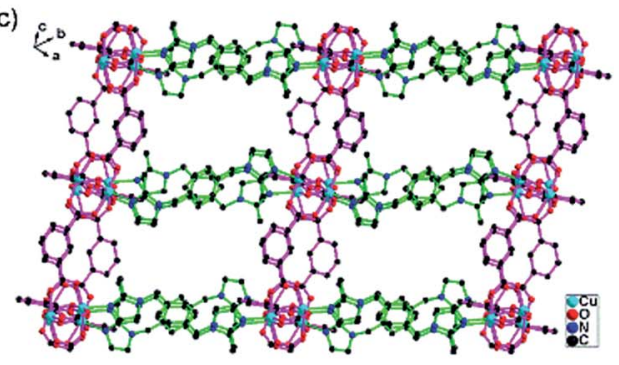

(d)

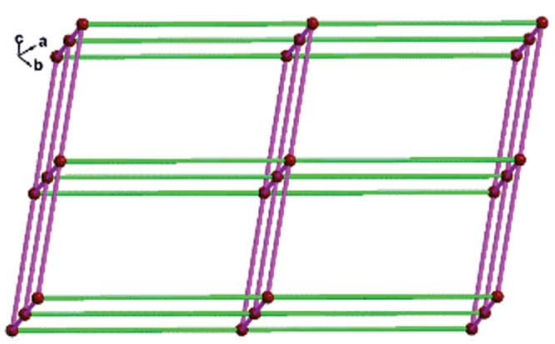

(e)

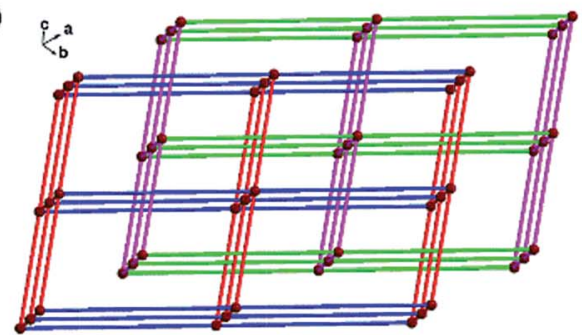

Fig. 2 (a) The coordination environment of the $\mathrm{Cu}(\mathrm{II})$ atoms in 2; (b) the $\left[\mathrm{Cu}_{2}(\mathrm{ip})_{2}\right]_{n}$ two-dimensional network in 2; (c) the 3D network in 2; (d) schematic depiction of the 3D pcu net in 2 . Black red balls show the $\left[\mathrm{Cu}_{2}(\mathrm{COO})_{4}\right]$ dimers. Bright green and pink sticks exhibit the bix and ip bridging ligands; (e) schematic depiction of the 2-fold interpenetrating 3D pcu net in 2.

imidazole nitrogen atom from one bix ligand (N1) in the apical position in the distorted square-pyramidal configuration (Fig. 2a). The $\mathrm{Cu} 2$ atom is coordinated by four carboxylate oxygen atoms from four ip ligands $(\mathrm{O} 3 \mathrm{~B}, \mathrm{O} 4 \mathrm{D}, \mathrm{O} 7, \mathrm{O} 8 \mathrm{C})$ and one imidazole nitrogen atom from one bix ligand (N3) in the distorted square-pyramidal configuration. The structural distortion index $\tau$ for $\mathrm{Cu} 1$ and $\mathrm{Cu} 2$ atoms are 0.007 and 0.014 , respectively. ${ }^{21}$

There are two independent ip ligands. All carboxylate groups (O1O2, $03 \mathrm{O} 4, \mathrm{O} 5 \mathrm{O} 6, \mathrm{O} 7 \mathrm{O} 8)$ of the ip ligands exhibit bridging mode structure (Fig. S3 in ESI†). The ip ligands link the $\mathrm{Cu}(\mathrm{II})$ atoms and construct the $\left[\mathrm{Cu}_{2}(\mathrm{ip})_{2}\right]_{n}$ two-dimensional network (Fig. 2b). The adjacent $\left[\mathrm{Cu}_{2}(\mathrm{ip})_{2}\right]_{n}$ two-dimensional networks are connected by bix ligands and construct the three-dimensional network (Fig. 2c).

Topologically, the $\left[\mathrm{Cu}_{2}(\mathrm{COO})_{4}\right]$ dimers are simplified as 6connected nodes (Fig. S4 in ESI $\dagger$ ). The ip and bix ligands are 2connected. The 3D network can be described as a 6-connected 3D pcu network based on the $\left[\mathrm{Cu}_{2}(\mathrm{COO})_{4}\right]$ dimers (Fig. 2d). Moreover, two identical 3D networks are still mutually interpenetrated to generate the 2-fold interpenetrating 3D pcu network because of the porous nature of the single network (Fig. 2e).

\section{Crystal structure of $\left[\mathrm{Cu}_{2}(\mathrm{bix})(\mathrm{Meip})_{2}\right]_{n}$ (3)}

3 exhibits the 2-fold interpenetrating three-dimensional pcu network based on the $\left[\mathrm{Cu}_{2}(\mathrm{COO})_{2}\right]$ and $\left[\mathrm{Cu}_{2}(\mathrm{COO})_{4}\right]$ dimers. The asymmetric unit of 3 consists of two $\mathrm{Cu}$ (II) atoms (Cu1, $\mathrm{Cu} 2$ ), two halves bix (N1N2, N3N4) and two Meip ligands (O1-O4, O5O8). The Cu1 atom is coordinated by four carboxylate oxygen atoms from four Meip ligands (O1, O5, O2A, O6A) in the equation positions and one imidazole nitrogen atom from one bix ligand (N2) in the apical position in the distorted square- pyramidal configuration (Fig. 3a) with the structural distortion index $\tau$ 0.003. The $\mathrm{Cu} 2$ atom is coordinated by four carboxylate oxygen atoms from four Meip ligands (O3, O4, O7C, $\mathrm{O} 8 \mathrm{~B}$ ) and one imidazole nitrogen atom from one bix ligand (N4) in the middle of distorted square-pyramidal configuration and trigonal-bipyramidal configuration with the structural distortion index $\tau$ 0.499. ${ }^{21}$

There are two kinds of Meip ligands. The carboxylate groups (01O2, O5O6, O7O8) of the Meip ligands exhibit bridging mode and connect two $\mathrm{Cu}(\mathrm{II})$ atoms (Fig. S5 in ESI†). One carboxylate group (O3O4) of one Meip ligand shows the chelating mode and links one $\mathrm{Cu} 2$ atom. The $\mathrm{Cu} 1$ and $\mathrm{Cu} 1 \mathrm{~A}$ atoms are connected by four Meip ligands to form $\left[\mathrm{Cu}_{2}(\mathrm{COO})_{4}\right]$ paddle wheel structure. However the $\mathrm{Cu} 2$ and $\mathrm{Cu} 2 \mathrm{~F}$ atoms are joined by two Meip ligands to form the $\left[\mathrm{Cu}_{2}(\mathrm{COO})_{2}\right]$ dimer. Two kinds of Meip ligands link the $\mathrm{Cu}(\mathrm{II})$ atoms and construct the $\left[\mathrm{Cu}_{2}(\mathrm{Meip})_{2}\right]_{n}$ two-dimensional network (Fig. 3b). The adjacent $\left[\mathrm{Cu}_{2}(\mathrm{Meip})_{2}\right]_{n}$ two-dimensional networks are connected by bix ligands and construct the three-dimensional network (Fig. 3c).

Topologically, the $\left[\mathrm{Cu}_{2}(\mathrm{COO})_{2}\right]$ and $\left[\mathrm{Cu}_{2}(\mathrm{COO})_{4}\right]$ dimers are deemed as 6-connected nodes (Fig. S6 and S7 in ESI†े). The Meip and bix ligands are 2-connected. The 3D network can be described as a 6-connected 3D pcu network based on the $\left[\mathrm{Cu}_{2}(\mathrm{COO})_{2}\right]$ and $\left[\mathrm{Cu}_{2}(\mathrm{COO})_{4}\right]$ dimers (Fig. $3 \mathrm{~d}$ ). Moreover, two identical 3D networks are still mutually interpenetrated to generate the 2 -fold interpenetrating 3D pcu network because of the porous nature of the single network (Fig. 3e).

Crystal structure of $\left\{\left[\mathrm{Cu}_{2}(\text { bix })(\mathrm{pbda})_{2}\right] \cdot \mathrm{H}_{2} \mathrm{O}\right\}_{n}(4)$

4 shows an unusual 6-connected self-catenated 3D network based on $\left[\mathrm{Cu}_{2}(\mathrm{COO})_{4}\right]$ dimers. The asymmetry unit consists of one 
(a)

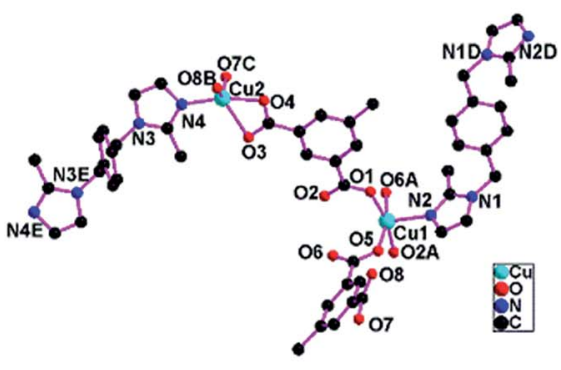

(b)

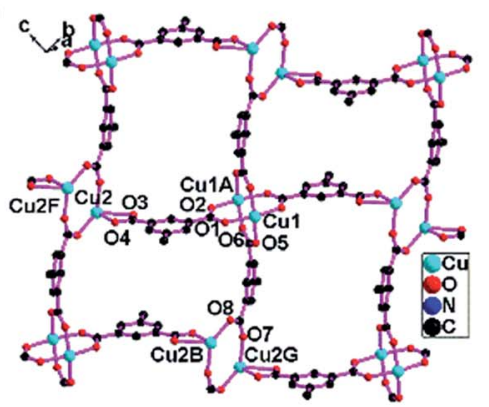

(c)

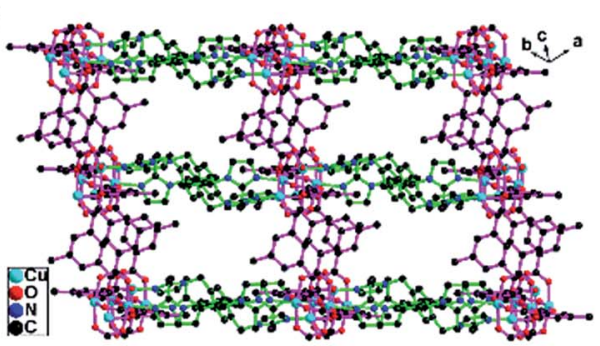

(d)

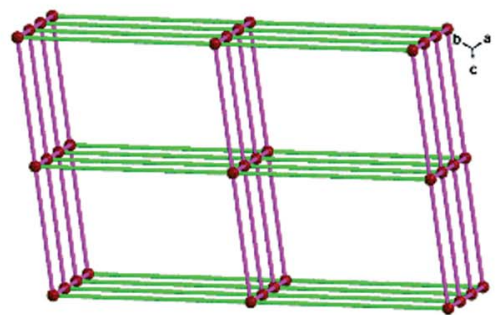

(e)

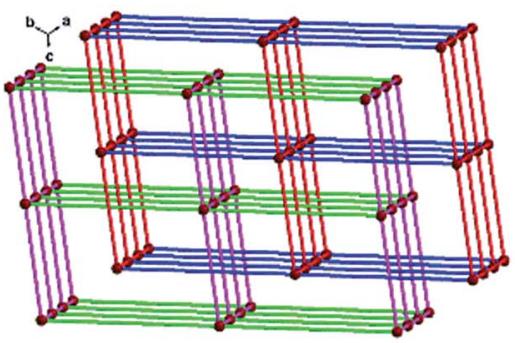

Fig. 3 (a) The coordination environment of $\mathrm{Cu}(I)$ atom in 3; (b) the $\left[\mathrm{Cu}_{2}(\mathrm{Meip})_{2}\right]_{n}$ two-dimensional network in 3; (c) the 3D network in 3; (d) schematic depiction of the 3D pcu net in 3 ; black red balls show the $\left[\mathrm{Cu}_{2}(\mathrm{COO})_{2}\right]$ and $\left[\mathrm{Cu}_{2}(\mathrm{COO})_{4}\right]$ dimers. Bright green and pink sticks exhibit the bix and Meip bridging ligands; (e) schematic depiction of the 2-fold interpenetrating 3D pcu net in 3.

$\mathrm{Cu}(\mathrm{II})$, half bix and two halves pbda. Each $\mathrm{Cu}$ (II) atom is coordinated by one imidazole nitrogen atom from one bix ligand (N1) and four carboxylate oxygen atoms from four pbda ligands (O1, $\mathrm{O} 3, \mathrm{O} 2 \mathrm{~A}, \mathrm{O} 4 \mathrm{~A}$ ) in a distorted square-pyramidal coordination geometry (Fig. 4a). The structural distortion index $\tau$ is 0.0025 , indicating that the coordination environment of $\mathrm{Cu}$ (II) atom is very closer to a square-pyramidal than a trigonal-bipyramidal configuration. ${ }^{21}$ Each carboxylate group of one pbda ligand shows bidentate bridging mode. Each pbda ligand acts as a tetradentate bridge and joins four $\mathrm{Cu}(\mathrm{II})$ atoms (Fig. S8 in ESI†).

Two $\mathrm{Cu}(\mathrm{II})$ atoms are connected by four pbda ligands and form the $\left[\mathrm{Cu}_{2}(\mathrm{COO})_{4}\right]$ paddle wheel structure. Each $\left[\mathrm{Cu}_{2}(\mathrm{COO})_{4}\right]$ dimer connects four $\left[\mathrm{Cu}_{2}(\mathrm{COO})_{4}\right]$ through pbda ligands (Fig. 4b) and extend to construct the $\left[\mathrm{Cu}_{2}(\mathrm{pbda})_{2}\right]_{n} 3 \mathrm{D}$ (a)

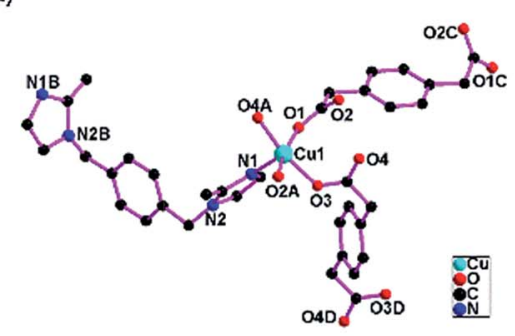

(d)

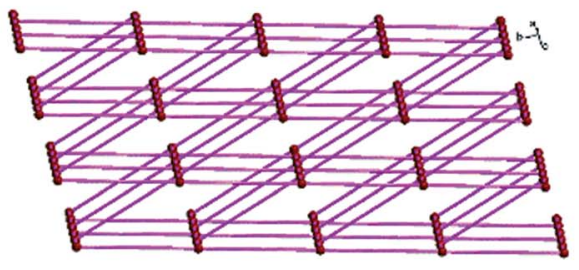

(b)

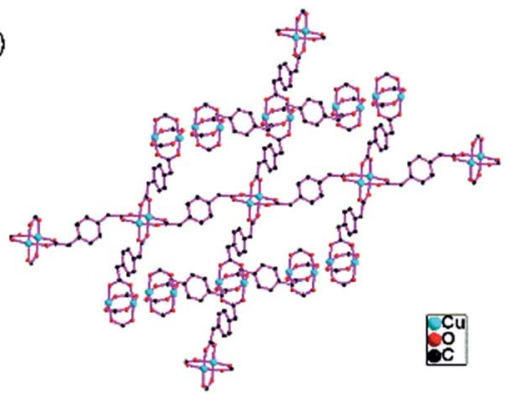

(e)

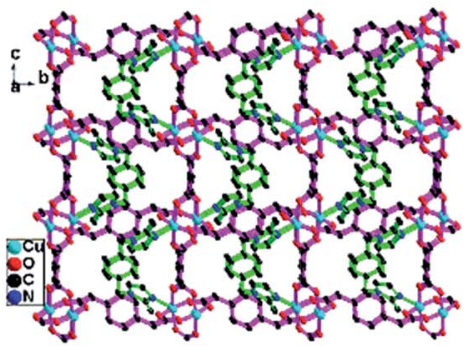

(c)

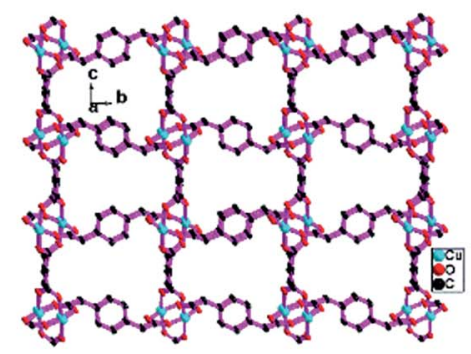

(f)

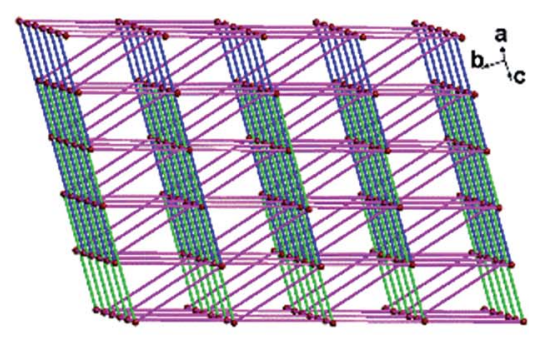

Fig. 4 (a) The coordination environment of $\mathrm{Cu}(I)$ atom in 4 ; (b) the connected mode of 4-connected $\left[\mathrm{Cu}_{2}(\mathrm{COO})_{4}\right]$ dimer in 4 ; $(\mathrm{c})$ the $\left[\mathrm{Cu}{ }_{2}-\right.$ $\left.(\mathrm{pbda})_{2}\right]_{n} 3 \mathrm{D}$ network in 4 ; (d) schematic depiction of the 4-connected $\left[\mathrm{Cu}_{2}(\mathrm{pbda})_{2}\right]_{n} 3 \mathrm{D}$ network based on $\left[\mathrm{Cu}_{2}(\mathrm{COO})_{4}\right]$ dimers in $4 . \mathrm{Black}$ red balls show the $\left[\mathrm{Cu}_{2}(\mathrm{COO})_{4}\right]$ dimers. Pink sticks exhibit the pbda ligands; (e) the $\left[\mathrm{Cu}_{2}(\mathrm{bix})(\mathrm{pbda})_{2}\right]_{n} 3 \mathrm{D}$ network in 4 ; (f) schematic depiction of the 6 -connected $\left[\mathrm{Cu}_{2}(\mathrm{bix})(\mathrm{pbda})_{2}\right]_{n} 3 \mathrm{D}$ network based on $\left[\mathrm{Cu}_{2}(\mathrm{COO})_{4}\right]$ dimers in 4 . Black red balls show the $\left[\mathrm{Cu}_{2}(\mathrm{COO})_{4}\right]$ dimers. Blue and bright green sticks both exhibit bix ligands for clarity. Pink sticks show pbda ligands. 
network (Fig. 4c). Topologically, the $\left[\mathrm{Cu}_{2}(\mathrm{COO})_{4}\right]$ node is 4connected and pbda ligand is 2-connected, if the $\left[\mathrm{Cu}_{2}(\mathrm{COO})_{4}\right]$ is simplified as one node. This $\left[\mathrm{Cu}_{2}(\mathrm{pbda})_{2}\right]_{n} 3 \mathrm{D}$ network is simplified as a 4-connected 3D network with the point symbol of $\left(6^{5} \cdot 8\right)$ (Fig. $\left.4 \mathrm{~d}\right) .^{22}$

The bix ligands show the gauche-conformation. The selfcatenated $\left[\mathrm{Cu}_{2}(\mathrm{pbda})_{2}\right]_{n}$ 3D network is linked by bix ligands to construct new self-catenated $\left[\mathrm{Cu}_{2}(\mathrm{bix})(\mathrm{pbda})_{2}\right]_{n}$ 3D network (Fig. 4e). Topologically, the $\left[\mathrm{Cu}_{2}(\mathrm{COO})_{4}\right]$ nodes are 6-connected, pbda and bix ligands are 2-connected, if the $\left[\mathrm{Cu}_{2}(\mathrm{COO})_{4}\right]$ is simplified as one node. This $\left[\mathrm{Cu}_{2}(\text { bix })(\text { pbda })_{2}\right]_{n} 3 \mathrm{D}$ network is simplified as a 6-connected self-catenated 3D network with the point symbol of $\left(4^{4} \cdot 6^{10} \cdot 8\right)$ (Fig. 4 f). ${ }^{22}$ The self-catenated motifs are few in the literature. ${ }^{23}$ This self-catenated $3 \mathrm{D}$ network is not reported, as to best of our knowledge.

\section{Crystal structure of $\left\{\left[\mathrm{Cu}_{2}(\mathrm{bix})_{1.5}(2,5-\mathrm{pydc})_{2}\left(\mathrm{H}_{2} \mathrm{O}\right)\right] \cdot 2 \mathrm{H}_{2} \mathrm{O}\right\}_{n}(5)$}

5 exhibits a $(3,4)$-connected $2 \mathrm{D}$ network with the point symbol of $\left(4^{2} \cdot 6\right)\left(4^{2} \cdot 6^{3} \cdot 8\right)$. The asymmetric unit of 5 consists of two $\mathrm{Cu}$ (II) atoms, one and a half bix, two 2,5-pydc, one coordinated water and disordered lattice water molecules. The Cu1 atom is five-coordinated with two carboxylate oxygen atoms $(\mathrm{O} 1, \mathrm{O} 7)$ from two 2,5-pydc, two nitrogen atoms from one bix (N4A) and one 2,5-pydc (N7) in the equation plane and one water oxygen atom (O9) in the apical position in a distorted square-pyramidal configuration. The $\mathrm{Cu} 2$ atom is fivecoordinated with one carboxylate oxygen atom from one 2,5-pydc (O5B), three nitrogen atoms from one 2,5-pydc (N8B) and two bix ligands (N2, N6) in the equation plane and one carboxylate oxygen atom (O3) from one 2,5-pydc in the apical position in the distorted square-pyramidal configuration (Fig. 5a). The structural distortion index $\tau$ for $\mathrm{Cu} 1$ and $\mathrm{Cu} 2$ atoms are 0.087 and 0.377 , respectively, indicating that the coordination environment of the $\mathrm{Cu} 1$ and $\mathrm{Cu} 2$ atom is closer to square-pyramidal geometry than trigonal-bipyramidal configuration and $\mathrm{Cu} 1$ atom is almost perfect squarepyramidal configuration. ${ }^{21}$

There are two independent 2,5-pydc ligands. All carboxylate groups (O1O2, O3O4, O5O6, O7O8) of the 2,5-pydc ligand exhibit monodentate mode. Each 2,5-pydc ligand connects two $\mathrm{Cu}$ (II) atoms through two carboxylate oxygen atoms and one pyridine nitrogen atom (O1O3N7, O5O7N8). All bix ligands act as bidentate bridging ligands and link two $\mathrm{Cu}(\mathrm{II})$ atoms (Fig. S9 in ESI $\dagger$ ). The $\mathrm{Cu}(\mathrm{II})$ atoms are connected by 2,5 -pydc and bix ligands to form a $2 \mathrm{D}$ network (Fig. 5b).

The topological analysis of $\mathbf{5}$ has been performed. Each Cu1 atom coordinates one bix and two 2,5-pydc ligands and is 3connected. Each $\mathrm{Cu} 2$ atom coordinates two bix and two 2,5pydc ligands and is 4-connected. All 2,5-pydc and bix ligands are 2 -connected nodes. The two-dimensional network of 5 can be simplified as a $(3,4)$-connected network (Fig. 5c) with the point symbol of $\left(4^{2} \cdot 6\right)\left(4^{2} \cdot 6^{3} \cdot 8\right) .{ }^{22}$ There are hydrogen bonding interactions between the coordination water and carboxylate oxygen atoms, between the coordination water and lattice water, between the lattice water and carboxylate oxygen atoms (Table S3 in ESI $\dagger$ ).
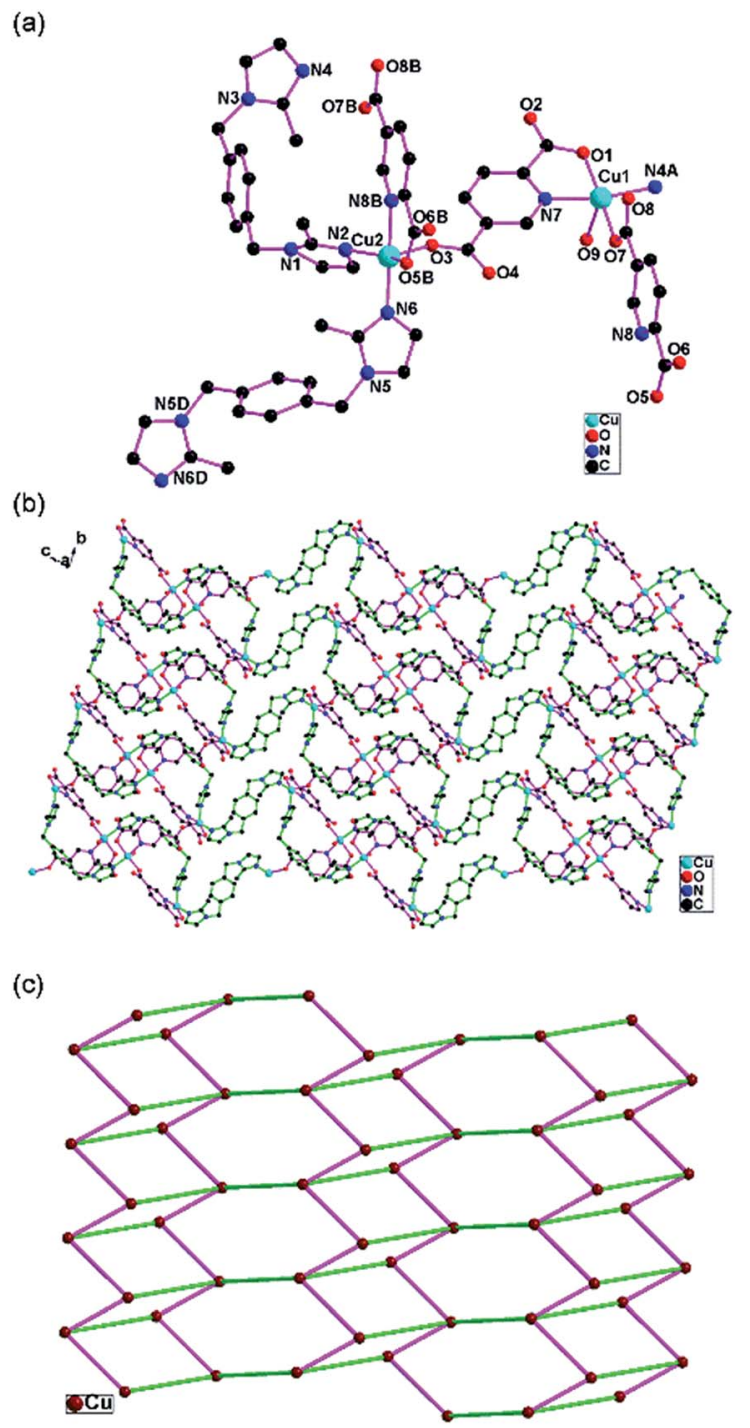

Fig. 5 (a) The coordination environment of $\mathrm{Cu}(\mathrm{II})$ atom in 5; (b) the $2 \mathrm{D}$ network in 5 ; (c) the $(3,4)$-connected $2 \mathrm{D}$ network in 5 . The pink and bright green sticks exhibit the 2,5-pydc and bix ligands, respectively. The pink and bright green sticks exhibit the 2,5-pydc and bix ligands.

\section{PXRD and solid-state diffuse-reflection study}

The measured and simulated PXRDs confirm the purity of 1-5 (Fig. S10-S14 in ESI $\dagger$ ). The optical diffuse reflection spectra of crystalline solids 1-5 were measured at room temperature. The absorption data were calculated from the reflectance using the Kubelka-Munk function. The energy band gaps $\left(E_{\mathrm{g}}\right)$ obtained by extrapolation of the linear portion of the absorption edges were estimated to be $2.21 \mathrm{eV}(1), 2.35 \mathrm{eV}(2), 2.41 \mathrm{eV}(3), 2.13 \mathrm{eV}$ (4), and $2.62 \mathrm{eV}$ (5), indicating their semiconductor nature (Fig. 6).

Catalytic activity for the degradation of methylene blue (MB), rhodamine B (RhB) and methyl orange (MO)

To study the photocatalytic activity of $\mathbf{1 - 5}$, we selected the organic dyes methylene blue (MB), rhodamine B (RhB) and 


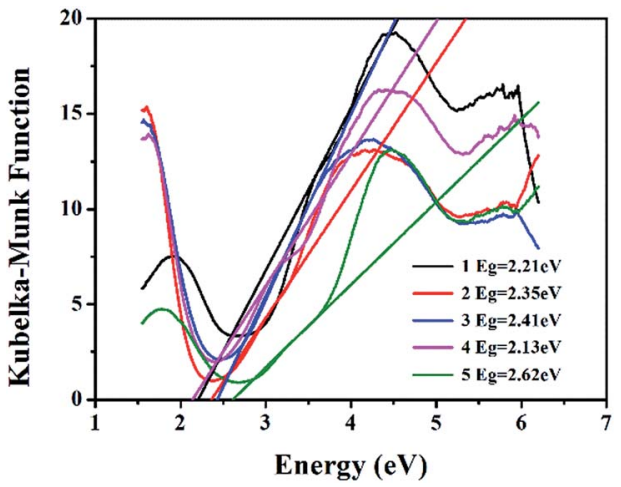

Fig. 6 Solid-state optical diffuse-reflection spectra of 1-5 derived from diffuse reflectance data at room temperature.

methyl orange (MO) as the model dye contaminants to evaluate the photocatalytic effectiveness in the purification of wastewater. The photocatalytic behaviors of 1-5 for the degradation of MB under visible light irradiation were shown in Fig. 7, 8 and Fig. S15-S18 (in ESI†). There is almost no degradation for the blank experiment (only $\mathrm{H}_{2} \mathrm{O}_{2}$, without light) for degradation of $\mathrm{MB}, \mathrm{RhB}$ and $\mathrm{MO}$. There is no significant degradation for the blank experiment (only light, without $\mathrm{H}_{2} \mathrm{O}_{2}$ ) and the control experiment with photocatalysts 1-5 in the absence of $\mathrm{H}_{2} \mathrm{O}_{2}$ under visible light irradiation. Meanwhile, the absorption peaks of MB were declined obviously with increasing time when 1-5 as heterogeneous catalysts in the presence of $\mathrm{H}_{2} \mathrm{O}_{2}$ under visible light irradiation for degradation of MB. After $90 \mathrm{~min}$, the degradation efficiencies of MB reached $94.0 \%$ for $\mathbf{1}, 90.7 \%$ for $2,89.1$ for $3,91.6$ for 4 and $82.8 \%$ for $\mathbf{5}$. Clearly, 1-5 were good photocatalysts for the degradation of MB. The catalytic efficiencies for degradation of $\mathrm{MB}$ are $\mathbf{1}>\mathbf{4}>\mathbf{2}>\mathbf{3}>\mathbf{5}$.

The photocatalytic behaviors of 1-5 for the degradation of RhB under visible light irradiation were shown in Fig. 9, 10 and Fig. S19-S22 (in ESI $\dagger$ ). The absorption peaks of RhB were declined obviously with increasing time when 1-5 as heterogeneous catalysts in the presence of $\mathrm{H}_{2} \mathrm{O}_{2}$ under visible light

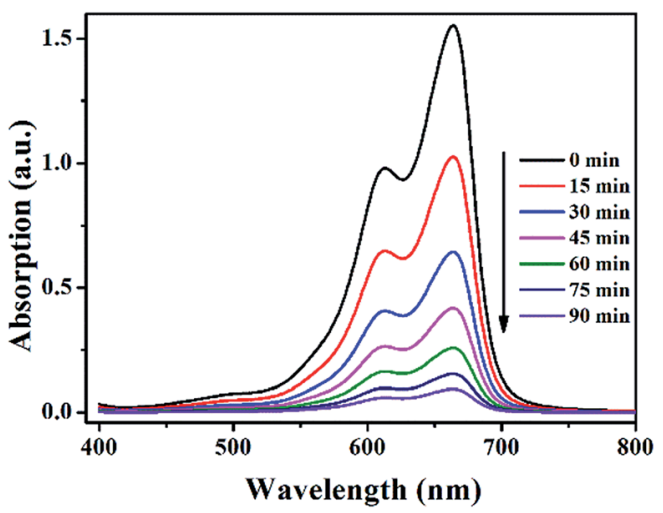

Fig. 7 The UV-vis absorption spectra of MB solution during photocatalytic degradation of the MB solution using catalyst 1 in the presence of $\mathrm{H}_{2} \mathrm{O}_{2}$ under visible light irradiation.

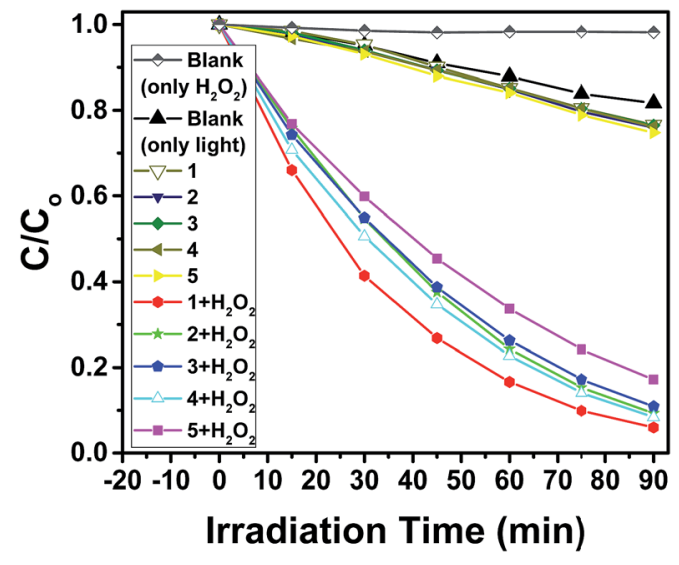

Fig. 8 Concentration changes of $\mathrm{MB}$ as a function of reaction time using catalysts 1-5 in the presence of $\mathrm{H}_{2} \mathrm{O}_{2}$, in the absence of $\mathrm{H}_{2} \mathrm{O}_{2}$ under visible light irradiation and the blank experiment only $\mathrm{H}_{2} \mathrm{O}_{2}$ or only visible light.

irradiation. After $180 \mathrm{~min}$, the degradation efficiencies of RhB reached $93.0 \%$ for $1,84.7 \%$ for $2,81.3$ for $3,88.6$ for 4 and $56.7 \%$ for 5 . There is no significant degradation for the blank experiment (only light, without $\mathrm{H}_{2} \mathrm{O}_{2}$ ) and the control experiment with photocatalysts 1-5 in the absence of $\mathrm{H}_{2} \mathrm{O}_{2}$ under visible light irradiation as comparison. 1-5 were effective photocatalysts for the degradation of RhB. The catalytic efficiencies for degradation of RhB are $1>4>2>3>5$.

The photocatalytic behaviors of 1-5 for the degradation of MO under visible light irradiation were shown in Fig. 11, 12 and Fig. S23-S26 (in ESI $\dagger$ ). The degradation efficiencies of MO reached $92.7 \%$ for $1,85.1 \%$ for $2,77.2$ for $3,87.3$ for 4 and $64.1 \%$ for 5 after 300 min when 1-5 as heterogeneous catalysts in the presence of $\mathrm{H}_{2} \mathrm{O}_{2}$ under visible light irradiation. As comparison, there is no significant degradation for the blank experiment (only light, without $\mathrm{H}_{2} \mathrm{O}_{2}$ ) and the control experiment with photocatalysts 1-5 in the absence of $\mathrm{H}_{2} \mathrm{O}_{2}$ under visible light irradiation. Therefore, 1-5 were effective photocatalysts for the degradation of MO. The catalytic efficiencies for the degradation of MO are $\mathbf{1}>4>2>3>5$.

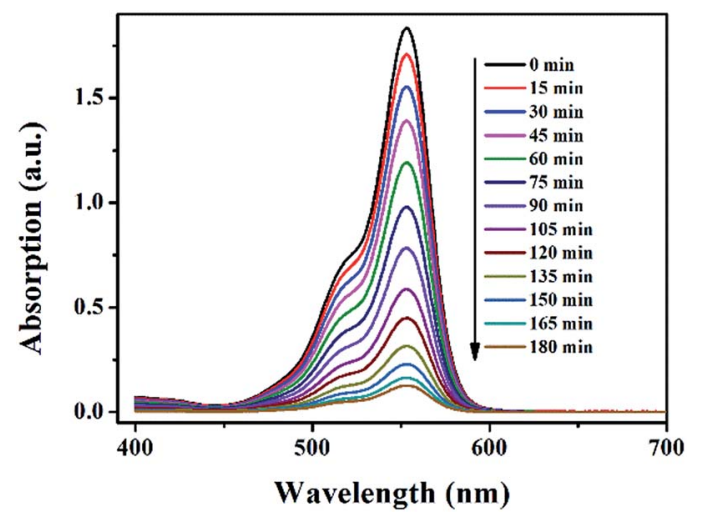

Fig. 9 The UV-vis absorption spectra of RhB solution during photocatalytic degradation of the RhB solution using catalyst 1 in the presence of $\mathrm{H}_{2} \mathrm{O}_{2}$ under visible light irradiation. 


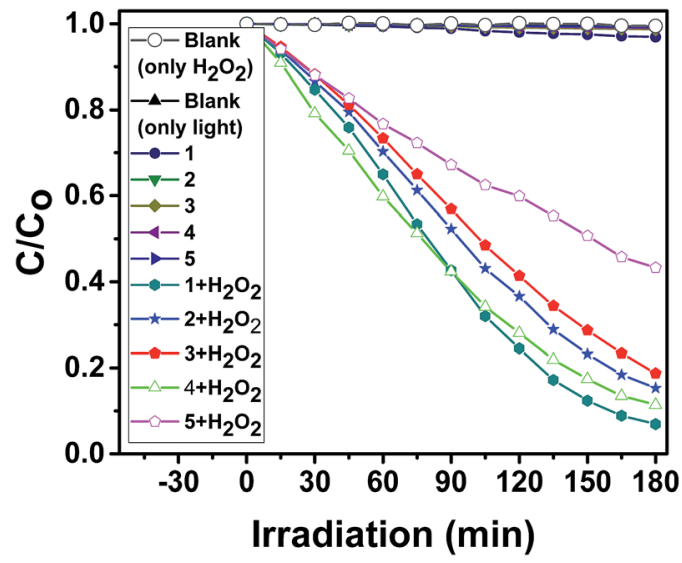

Fig. 10 Concentration changes of $\mathrm{RhB}$ as a function of reaction time using catalysts 1-5 in the presence of $\mathrm{H}_{2} \mathrm{O}_{2}$, in the absence of $\mathrm{H}_{2} \mathrm{O}_{2}$ under visible light irradiation and the blank experiment only $\mathrm{H}_{2} \mathrm{O}_{2}$ or only visible light.

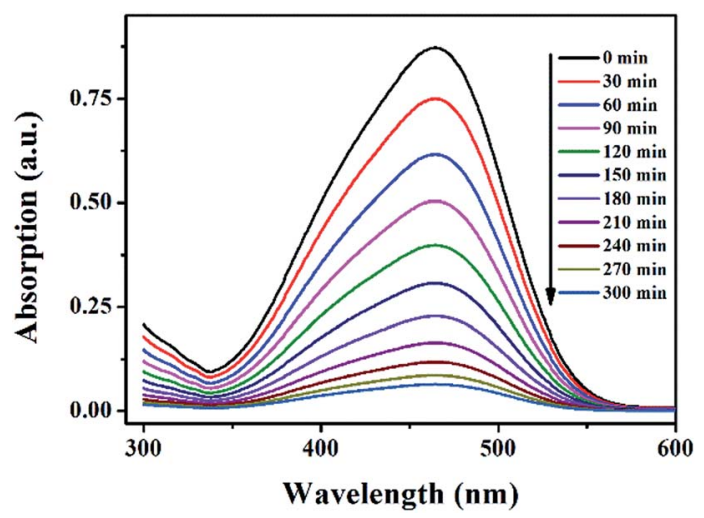

Fig. 11 The UV-vis absorption spectra of MO solution during photocatalytic degradation of the MO solution using catalyst 1 in the presence of $\mathrm{H}_{2} \mathrm{O}_{2}$ under visible light irradiation.

After the photocatalytic degradation of the organic dyes MB, $\mathrm{RhB}$ and MO solutions, the photocatalysts 1-5 can be easily separated by simple centrifugation because they are undissolved in water. After the photocatalysis, the PXRD patterns of 1-5 are in good agreement with that of the original compounds, implying that 1-5 maintain their structural integrity after the photocatalysis reaction (Fig. S10-S14 in ESI $\dagger$ ). The photocatalysts 1-5 can be recovered from the catalytic system and reused for five catalytic cycles (Fig. S27-S31 in ESI $\dagger$ ). The photocatalytic experiment proves that $\mathbf{1}, \mathbf{2}$ and $\mathbf{4}$ are highly efficient and universal photocatalysts for degradation of the organic dyes $\mathrm{MB}, \mathrm{RhB}$ and $\mathrm{MO}$ (Fig. 13).

$\mathrm{H}_{2} \mathrm{O}_{2}$ is a good oxide and the precursor of hydroxyl radical $\left({ }^{\circ} \mathrm{OH}\right)$, which is an effective and highly active oxidizing species for decomposing organic dyes into nonpolluting simple molecules, or $\mathrm{CO}_{2}$ and $\mathrm{H}_{2} \mathrm{O} .{ }^{24}$ In order to find out whether hydroxyl radical $\left({ }^{\circ} \mathrm{OH}\right)$ is participated in the photocatalytic degradation process or not, the photocatalytic reaction using catalyst 1 in the presence of $\mathrm{H}_{2} \mathrm{O}_{2}$ and good hydroxyl radical ( $\left.{ }^{\circ} \mathrm{OH}\right)$ scavenger mannitol $(1.0 \mathrm{~g})$ for degradation of $\mathrm{MB}$, RhB and $\mathrm{MO}$ under

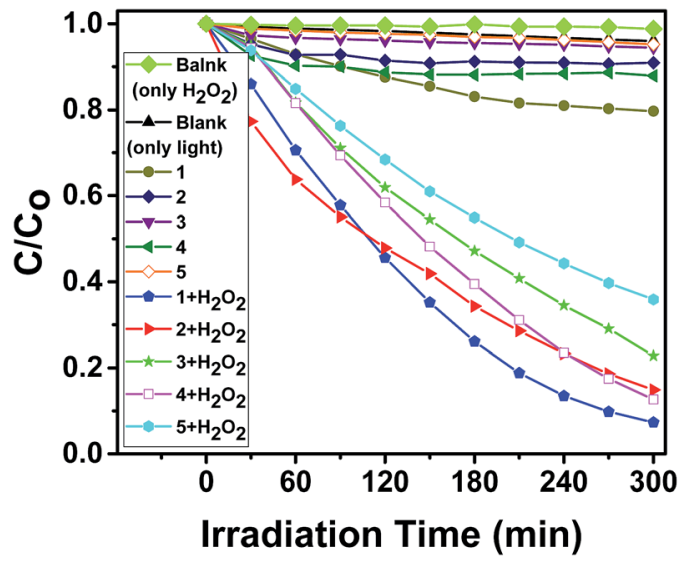

Fig. 12 Concentration changes of $\mathrm{MO}$ as a function of reaction time using catalysts 1-5 in the presence of $\mathrm{H}_{2} \mathrm{O}_{2}$, in the absence of $\mathrm{H}_{2} \mathrm{O}_{2}$ under visible light irradiation and the blank experiment only $\mathrm{H}_{2} \mathrm{O}_{2}$ or only visible light.

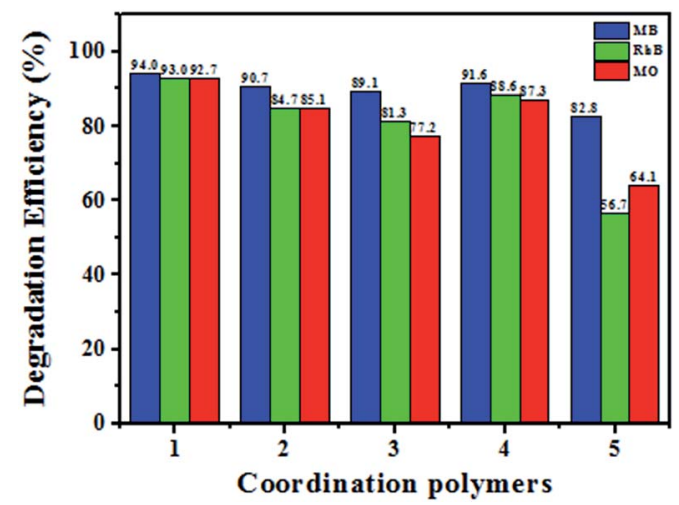

Fig. 13 Photocatalytic degradation efficiency of the MB, RhB and MO using catalysts $1-5$ in the presence of $\mathrm{H}_{2} \mathrm{O}_{2}$ under visible light irradiation.

visible light irradiation was performed for comparison. The degradation efficiencies of $\mathrm{MB}$ using catalyst 1 in the absence of $\mathrm{H}_{2} \mathrm{O}_{2}$, in the presence of $\mathrm{H}_{2} \mathrm{O}_{2}$, in the presence of $\mathrm{H}_{2} \mathrm{O}_{2}$ and mannitol for degradation of $\mathrm{MB}$ were $23.4 \%, 94.0 \%$ and $39.4 \%$, after 90 min (Fig. S32 in ESI $\dagger$ ). The degradation efficiencies of RhB using catalyst 1 in the absence of $\mathrm{H}_{2} \mathrm{O}_{2}$, in the presence of $\mathrm{H}_{2} \mathrm{O}_{2}$, in the presence of $\mathrm{H}_{2} \mathrm{O}_{2}$ and mannitol for degradation of RhB were $3.1 \%, 93.1 \%$ and $12.6 \%$, after 180 min (Fig. S33 in ESI $\dagger$ ). The degradation efficiencies of MO using catalyst 1 in the absence of $\mathrm{H}_{2} \mathrm{O}_{2}$, in the presence of $\mathrm{H}_{2} \mathrm{O}_{2}$, in the presence of $\mathrm{H}_{2} \mathrm{O}_{2}$ and mannitol for degradation of $\mathrm{MO}$ were $20.3 \%, 92.7 \%$ and $28.0 \%$, after 300 min (Fig. S34 in ESI $\dagger$ ). The experimental results show that $\mathrm{H}_{2} \mathrm{O}_{2}$ can greatly increase the photocatalytic efficiency and the good hydroxyl radical $\left({ }^{\circ} \mathrm{OH}\right)$ scavenger mannitol can inhibit the photocatalytic reaction. Therefore, hydroxyl radical ( $\left.{ }^{\circ} \mathrm{OH}\right)$ should participate in the photocatalytic degradation process.

During the photocatalytic process, upon irradiation by visible light, the absorption of energy is equal to or greater than the energy band gap of photocatalysts $(h \nu \geqq 2.21 \mathrm{eV}$ for $\mathbf{1}$, 
$2.35 \mathrm{eV}$ for $2,2.41 \mathrm{eV}$ for $3,2.13 \mathrm{eV}$ for $4,2.62 \mathrm{eV}$ for 5), the electrons in the highest occupied molecular orbital (HOMO) are excited to the lowest unoccupied orbital (LUMO). The charge transfer excited state of photocatalyst can be deactivated by oxidizing the contaminant directly and/or oxygenating $\mathrm{H}_{2} \mathrm{O}$ or $\mathrm{H}_{2} \mathrm{O}_{2}$ into a hydroxyl radical $\left({ }^{\circ} \mathrm{OH}\right)$. The hydroxyl radical $\left({ }^{\circ} \mathrm{OH}\right)$ can oxidize the organic dyes into nonpolluting simple molecules, or $\mathrm{CO}_{2}$ and $\mathrm{H}_{2} \mathrm{O}$ to complete the photocatalytic process. $^{7-17}$

The above photocatalytic reaction shows that the catalytic efficiencies for the degradation of $\mathrm{MB}, \mathrm{RhB}$ and $\mathrm{MO}$ are $\mathbf{1}>\mathbf{4}>\mathbf{2}$ $>3>5$. The lower energy band gap $\left(E_{\mathrm{g}}\right)$ of the photocatalysts (Coordination Polymers) usually can present the high catalytic efficiency. The other factors such as coordination configuration of the metal centers and the structures of the photocatalysts (Coordination Polymers) also play the important role in the degradation rates of the photocatalysts. The $\mathrm{Cu}(\mathrm{II})$ atoms in $\mathbf{2 - 4}$ all have an unsaturated five-coordinated distorted squarepyramidal configuration. We speculate that the thermodynamic stable $\left[\mathrm{Cu}_{2}(\mathrm{COO})_{4}\right]$ paddle wheel structures are favourably formed in $\mathbf{2 - 4}$ and the $\mathrm{Cu}(\mathrm{II})$ atoms in $\left[\mathrm{Cu}_{2}(\mathrm{COO})_{4}\right]$ paddle wheel structures all exhibit the distorted square-pyramidal configuration because each copper(II) atom in $\left[\mathrm{Cu}_{2}(\mathrm{COO})_{4}\right]$ hinders the coordination of the other copper(II) atom. The $\mathrm{Cu}$ (II) atoms in 5 maybe accidently show an unsaturated fivecoordinated distorted square-pyramidal configuration. But the $\mathrm{Cu} 1$ atoms and $\mathrm{Cu} 2$ atoms in $\mathbf{1}$ have an unsaturated fourcoordinated distorted square geometry and an unsaturated five-coordinated distorted square-pyramidal configuration, respectively. We speculate that each copper(II) atom in the $\left[\mathrm{Cu}_{2}(\mu-\mathrm{OH})\right]$ dimer hiders the coordination of the other copper(II) atom and the copper(II) show the unsaturated fourcoordinated and five-coordinated configurations in $\mathbf{1}$. The highly photocatalytic activity of $\mathbf{1}$ can be attributed to the lower energy band gap and the $\mathrm{Cu}(\mathrm{II})$ atom with unsaturated fourcoordinated distorted square geometry.

Chemistry researchers usually select one organic dye as model contaminant to study the photocatalytic properties of photocatalysts. ${ }^{7-12}$ Only few researches choose two or more model dyes. ${ }^{13,14}$ The photocatalysts usually exhibit the selectivity of photocatalytic activities for degradation of unique organic dye. Highly efficient and universal photocatalysts are seldom observed. ${ }^{13,14}$ For example, Wang and coworkers reported five polyoxometalate-based Cu(II) MOFs which show the selectivity photocatalytic degradation of three organic dyes methylene blue (MB), rhodamine B (RhB) and methyl orange (MO) under UV irradiation. Three compounds are good candidates for the photocatalytic degradation of $\mathrm{MB}$, and one compound is a good photocatalyst for the degradation of $\mathrm{RhB}^{13 c}$ Zhang and coworkers synthesized two isomeric two-dimensional copper(I) coordination polymers $\mathrm{Cu}(\mathrm{ptz})$ which showed high photocatalytic efficiency for the degradation of $\mathrm{MB}, \mathrm{RhB}$, and $\mathrm{MO}$ in aqueous solution under xenon arc lamp irradiation. ${ }^{14 b}$ Wang and coworkers reported a $3 \mathrm{D}$ polyoxomolybdate-organic framework, $\left\{\left[\mathrm{Cu}_{3}\left(\mathrm{H}_{3} \mathrm{tpb}\right)_{2}(\mathrm{tpb})\left(\mathrm{Mo}_{4} \mathrm{O}_{12}\right)\right] \cdot 4 \mathrm{H}_{2} \mathrm{O}\right\}_{n}$ which exhibits remarkable photocatalytic activities for decomposition of $\mathrm{MO}$, methylene red (MR), MB, methylene violet (MV) and RhB under
UV light. ${ }^{14 c} \mathrm{Yu}$, Zhou and coworkers synthesized five molybdophosphate coordination polymers. One coordination polymer as a representative catalyst exhibits a universal highly efficient degradation ability for typical dyes MB, MO, and RhB under UV light. ${ }^{14 d} \mathrm{Wu}$ and coworkers reported four anionic zwitterionPOM hybrid materials which demonstrate remarkable efficiency for selective scavenging and photolysis of cationic dyes from polluted water. ${ }^{14 e}$ Zhu and coworkers synthesized three copper(II) porous coordination polymers which show high catalytic activities for the degradation of rhodamine $\mathrm{B}(\mathrm{RhB})$, methylene blue (MB), safranine T (ST), and orange II (OII) dyes in aqueous solution. ${ }^{14 f}$

In the present work, five copper(II) coordination polymers based on 1,4-bis(2-methyl-imidazol-1-ylmethyl)benzene (bix) and different multicarboxylate 1,2,4-benzenetricarboxylate (1,2,4-btc), isophthalate (ip), 5-methyl-isophthalate (Meip), 1,4benzenediacatate (pbda) and 2,5-pyridine-dicarboxylate (2,5pydc) were synthesized. 1-5 exhibit diverse structures and are highly efficient and universal photocatalysts for the degradation of the organic dyes methylene blue (MB), rhodamine B (RhB) and methyl orange (MO) under visible light irradiation. The structures and properties of coordination polymers based on bix ligand in literatures are summarized here for discussion and comparison. $^{25} \quad\left[\mathrm{Cu}(\mathrm{Hbtc})(\mathrm{bix})_{0.5}\right]_{n} \quad\left(\mathrm{H}_{3}\right.$ btc $=$ 1,3,5-benzenetricarboxylic acid) exhibits a 3D (4,5)-connected net and catalytic degradation of methyl orange in photo Fenton like process in the presence of sodium persulfate under UV irradiation. ${ }^{25 a} \mathrm{~A}$ pair of $\mathrm{Cu}(\mathrm{I})$ compound isomers $\left[\mathrm{Cu}_{2}(\mathrm{CN})_{2}(\mathrm{bix})\right]$ generate a three-fold interpenetrated 3D uninodal $(10,3)$ network with $\mathrm{ThSi}_{2}$ and utq topology and show the strong green photoluminescence peak at $565 \mathrm{~nm}^{25 \boldsymbol{b}}$ Barbour and coworkers reported the single-crystal to single-crystal interconversion of four distinct molecular crystal forms consisting of neutral, dinuclear metal complexes using bix, $\mathrm{CuCl}_{2}$ and different solvents. ${ }^{25 c} \mathrm{~A}$ discrete rectangular complex $\left[\mathrm{Ag}_{2}(\mathrm{bix})_{2}\right]\left(\mathrm{BF}_{4}\right)_{2} \cdot 2 \mathrm{CH}_{3} \mathrm{CN}$ retains its solvent-templated channel structure on guest removal to yield a porous, gas sorbing material for $\mathrm{CO}_{2}, \mathrm{H}_{2}, \mathrm{CH}_{4}$ and $\mathrm{N}_{2}$ at room temperature $\left(30^{\circ} \mathrm{C}\right) .{ }^{25 d}\left\{\left[\mathrm{Ag}_{2}(\mathrm{bix})_{3}\right]\left(\mathrm{BF}_{4}\right)_{2}\right\}$ shows an infinite two-dimensional Borromean coordination framework. ${ }^{25 e} \mathrm{~A}$ $2 \mathrm{D}$ corrugated $(6,3)$ network $\left[\mathrm{Zn}(\mathrm{dpc})(\mathrm{bix})_{0.5}\right]_{n}$ and a $3 \mathrm{D}$ microporous framework $\left[\mathrm{Pb}(\mathrm{dpc})(\mathrm{bix})_{0.5}\right]_{n}(\mathrm{dpc}=$ dipicolinate $)$ show luminescence emission peaks at 416 and $441 \mathrm{~nm}$, respectively. ${ }^{25 f} \mathrm{~A} 3 \mathrm{D} \rightarrow 3 \mathrm{D}$ interpenetrated $\left[\mathrm{Ag}_{2}(\mathrm{bix})_{1.5}(\mathrm{pzdc}) \cdot 3 \mathrm{H}_{2} \mathrm{O}\right]_{n}$ and a $2 \mathrm{D} \rightarrow 3 \mathrm{D}$ polycatenated $\left[\mathrm{Ag}(\mathrm{bix})(\mathrm{mac})_{0.5} \cdot 0.5 \mathrm{H}_{2} \mathrm{O}\right]_{n}\left(\mathrm{H}_{2}\right.$ pydc $=$ pyrazine-2,3-dicarboxylic acid, $\mathrm{H}_{2}$ mac $=$ L-malic acid) exhibit luminescence emission peaks at 476 and $426 \mathrm{~nm}$, respectively. ${ }^{25 g}$ A one-dimensional $\left\{\left[\mathrm{Ag}_{3}(\text { bix })_{2}(\text { ndca })_{1.5}\right] \cdot \mathrm{H}_{2} \mathrm{O}\right\}_{n}\left(\mathrm{H}_{2}\right.$ ndca $=$ naphthalene-1,4-dicarboxylicacid) which exhibits a luminescence emission peak at $446 \mathrm{~nm} .{ }^{25 h}$ A 2-fold interpenetrated 3D pcu network $\left\{\left[\mathrm{Zn}(\text { fum })(\text { bix })_{0.5}\right] \cdot 0.5 \mathrm{H}_{2} \mathrm{O}\right\}_{n}\left(\mathrm{H}_{2}\right.$ fum $=$ fumaric acid) displays a luminescence emission peak at $453 \mathrm{~nm} \cdot{ }^{25 i}$ $\left\{\left[\mathrm{M}(\mathrm{bcpb})(\mathrm{bix})_{0.5}\right] \cdot x \mathrm{H}_{2} \mathrm{O}\right\}_{n}(\mathrm{M}=\mathrm{Co}(\mathrm{II}), \mathrm{Cu}(\mathrm{II}), \mathrm{Ni}(\mathrm{II})),\left(\mathrm{H}_{2} \mathrm{bcpb}=\right.$ 3,5-bis(4-carboxyphenyl)pyridine) are isomorphic and show complicated 3D (3,5)-coordinated amd networks, which could be viewed as two interpenetrated ths nets. ${ }^{25 j}\left\{\left[\mathrm{Ni}(\mathrm{tptc})_{0.5}(\mathrm{bix})\right]\right.$. $\left.0.25 \mathrm{H}_{2} \mathrm{O}\right\}_{n}\left(\mathrm{H}_{4}\right.$ tptc $=$ terphenyl-2,5,2',5'-tetracarboxylic acid $)$ shows an unprecedented 3D (4,4)-connected framework with 
the point Schläfli symbol of $\left(4 \cdot 6^{4} \cdot 8^{2}\right)_{2}\left(4^{2} \cdot 8^{4}\right) .^{25 k}\left[\mathrm{Cd}(\mathrm{bix})_{0.5}\right.$ (ndc) $] \cdot 1.5 \mathrm{H}_{2} \mathrm{O}\left(\mathrm{H}_{2}\right.$ ndc $=$ naphthalene-2,6-dicarboxylic acid) forms a 3-fold interpenetrated pcu network constructed from paddle-wheel second building blocks. ${ }^{25 l}[\mathrm{Cd}(\mathrm{L})(\mathrm{bix})]_{n}\left(\mathrm{H}_{2} \mathrm{~L}=4^{\prime}\right.$ ((2-carboxyphenoxy)methyl)biphenyl-2-carboxylic acid) displays a $2 \mathrm{D} \rightarrow 3 \mathrm{D}$ interdigitated framework and luminescent emissions at $426 \mathrm{~nm}^{25 m}\left[\mathrm{Zn}_{2}\left(\mu_{2}-\mathrm{OH}\right)(\text { boaba })(\text { bix })\right]_{n}\left(\mathrm{H}_{3}\right.$ boaba $=3,5$ bis-oxyacetate-benzoicacid) exhibits a $(3,5)$-connected bimodal gra net with binuclear $\left[\mathrm{Zn}_{2}\left(\mu_{2}-\mathrm{OH}\right)(\mathrm{COO})\right]$ clusters which shows blue photo-luminescence emissions at $416 \mathrm{~nm} .^{25 n}$

\section{Conclusions}

In summary, five structural diversity of five-coordinated copper(II) coordination polymers were synthesized. 1-5 are semiconducting in nature, with $E_{\mathrm{g}}$ of $2.21 \mathrm{eV}(1), 2.35 \mathrm{eV}(2), 2.41 \mathrm{eV}$ (3), $2.13 \mathrm{eV}$ (4), and $2.62 \mathrm{eV}$ (5). 1-5 are highly efficient and universal photocatalysts for the degradation of the organic dyes methylene blue (MB), rhodamine $\mathrm{B}(\mathrm{RhB})$ and methyl orange (MO) under visible light irradiation, and are very stable and easily separated from the reaction system for reuse. This work shows that the coordinated unsaturated copper coordination polymers should be very promising photocatalysts for degradation of organic dyes under visible light irradiation.

\section{Acknowledgements}

This work is supported by the Natural Science Foundation of China (No. 21171126), the Natural Science Foundation of Jiangsu Province (No. BK20161212), the Priority Academic Program Development of Jiangsu Higher Education Institutions, State and Local Joint Engineering Laboratory for Functional Polymeric Materials.

\section{References}

1 W. W. Li, H. Q. Yu and Z. He, Energy Environ. Sci., 2013, 7, 911-924.

2 (a) T. Aarthi and G. Madras, Catal. Commun., 2008, 9, 630634; (b) T. Jing, Y. Dai, W. Wei, X. C. Ma and B. B. Huang, Phys. Chem. Chem. Phys., 2014, 16, 18596-18604; (c) J. Di, J. Xia, Y. Ge, H. Li, H. Ji, H. Xu, Q. Zhang, H. Li and M. Li, Appl. Catal., B, 2015, 168, 51-61; (d) H. Wang, M. Miyauchi, Y. Ishikawa, A. Pyatenko, N. Koshizaki, Y. Li, L. Li, X. Li, Y. Bando and D. Golberg, J. Am. Chem. Soc., 2011, 133, 19102-19109; (e) Z. Sha, J. Sun, H. S. O. Chan, S. Jaenicke and J. Wu, RSC Adv., 2014, 4, 64977-64984.

3 (a) M. N. Chong, B. Jin and C. W. K. Chow, Water Res., 2010, 44, 2997-3027; (b) E. Piera, M. I. Tejedor-Tejedor, M. E. Zorn and M. A. Anderson, Appl. Catal., B, 2003, 46, 671-685.

4 (a) X. Chen and S. S. Mao, Chem. Rev., 2007, 107, 2891-2959; (b) A. Duta, A. Enesca, C. Bogatu and E. Gyorgy, Mater. Sci. Semicond. Process., 2016, 42, 94-97; (c) A. Enesca, M. Baneto, D. Perniu, L. Isac, C. Bogatu and A. Duta, Appl. Catal., B, 2016, 186, 69-76; (d) A. Enesca, L. Isac and A. Duta, Appl. Catal., B, 2015, 162, 352-363; (e) E. Thimsen, Q. Peng, A. B. F. Martinson, M. J. Pellin and J. W. Elam, Chem. Mater.,
2011, 23, 4411-4413; (f) S. H. Hwang, C. Kim and J. Jang, Catal. Commun., 2011, 12, 1037-1041; $(g)$ S. Chen, W. Zhao, W. Liu and S. Zhang, Appl. Surf. Sci., 2008, 255, 2478-2484.

5 (a) Z. C. Hu, B. J. Deibert and J. Li, Chem. Soc. Rev., 2014, 43, 5815-5840; (b) P. Q. Liao, D. D. Zhou, A. X. Zhu, L. Jiang, R. B. Lin, J. P. Zhang and X. M. Chen, J. Am. Chem. Soc., 2012, 134, 17380-17381; (c) M. Du, C. P. Li, C. S. Liu and S. M. Fang, Coord. Chem. Rev., 2013, 257, 1282-1305; (d) L. Fu, Y. Liu, M. Pan, X. J. Kuang, C. Yan, K. Li, S. C. Wei and C. Y. Su, J. Mater. Chem. A, 2013, 1, 8575-8580; (e) M. X. Li, Y. F. Zhang, X. He, X. M. Shi, Y. P. Wang, M. Shao and Z. X. Wang, Cryst. Growth Des., 2016, 16, 2912-2922.

6 (a) X. Zhao, X. H. Bu, Q. G. Zhai, H. Tran and P. Y. Feng, J. Am. Chem. Soc., 2015, 137, 1396-1399; (b) D. S. Li, J. Zhao, Y. P. Wu, B. Liu, L. Bai, K. Zou and M. Du, Inorg. Chem., 2013, 52, 8091-8098; (c) S. L. Huang, A. Q. Jia and G. X. Jin, Chem. Commun., 2013, 49, 2403-2405; (d) Z. Z. Lu, R. Zhang, Y. Z. Li, Z. J. Guo and H. G. Zheng, J. Am. Chem. Soc., 2011, 133, 4172-4174; (e) P. Yang, X. He, M. X. Li, Q. Ye, J. Z. Ge, Z. X. Wang, S. R. Zhu, M. Shao and H. L. Cai, J. Mater. Chem., 2012, 22, 2398-2400; (f) H. B. Zhou, J. H. Yao, X. P. Shen, H. Zhou and A. H. Yuan, $R S C A d v ., 2014$, 4, 61-70; (g) X. X. Liu, C. D. Shi, C. W. Zhai, M. L. Cheng, Q. Liu and G. X. Wang, ACS Appl. Mater. Interfaces, 2016, 8, 4585-4591.

7 (a) Y. Hu, F. Luo and F. F. Dong, Chem. Commun., 2011, 47, 761-763; (b) X. L. Wang, J. Luan, H. Y. Lin, C. Xu, G. C. Liu, J. W. Zhang and A. X. Tian, CrystEngComm, 2013, 15, 9995-10006; (c) Y. Q. Jiao, C. Qin, H. Y. Zang, W. C. Chen, C. G. Wang, T. T. Zheng, K. Z. Shao and Z. M. Su, CrystEngComm, 2015, 17, 2176-2189; (d) L. Liu, J. Ding, M. Li, X. Lv, J. Wu, H. Hou and Y. Fan, Dalton Trans., 2014, 43, 12790-12799; (e) L. L. Liu, C. X. Yu, F. J. Ma, Y. R. Li, J. J. Han, L. Lin and L. F. Ma, Dalton Trans., 2015, 44, 1636-1645; $(f)$ S. Y. Hao, S. X. Hou, K. V. Heckeb and G. H. Cui, Dalton Trans., 2017, 46, 19511964; (g) J. W. Cui, S. X. Hou, K. V. Heckeb and G. H. Cui, Dalton Trans., 2017, 46, 2892-2903.

8 (a) J. X. Meng, Y. G. Li, H. Fu, X. L. Wang and E. B. Wang, CrystEngComm, 2011, 13, 649-655; (b) Q. Wu, W. L. Chen, D. Liu, C. Liang, Y. G. Li, S. W. Lin and E. B. Wang, Dalton Trans., 2011, 40, 56-61; (c) X. He, K. Fang, X. H. Guo, J. Han, X. P. Lu and M. X. Li, Dalton Trans., 2015, 44, 13545-13549; (d) F. Q. Wang, C. M. Wang, Z. C. Yu, Q. G. He, X. Y. Li, C. L. Shang and Y. N. Zhao, RSC Adv., 2015, 5, 70086-70093.

9 (a) G. H. Cui, C. H. He, C. H. Jiao, J. C. Geng and V. A. Blatov, CrystEngComm, 2012, 14, 4210-4216; (b) M. Li, S. Zhao, Y. F. Peng, B. L. Li and H. Y. Li, Dalton Trans., 2013, 42, 9771-9776; (c) J. M. Hao, B. Y. Yu, K. V. Hecke and G. H. Cui, CrystEngComm, 2015, 17, 2279-2293; (d) W. Y. Yin, Z. L. Huang, X. Y. Tang, J. Wang, H. J. Cheng, Y. S. Ma, R. X. Yuan and D. Liu, New J. Chem., 2015, 39, 7130-7139.

10 (a) X. L. Wang, Z. H. Chang, H. Y. Lin, A. X. Tian, G. C. Liu, J. W. Zhang and D. N. Liu, CrystEngComm, 2015, 17, 895-903; (b) B. Mu and R. D. Huang, CrystEngComm, 2016, 18, 986- 
999; (c) X. L. Wang, Z. H. Chang, H. Y. Lin, A. X. Tian, G. C. Liu and J. W. Zhang, Dalton Trans., 2014, 43, 1227212278; (d) L. L. Liu, C. X. Yu, J. M. Du, S. M. Liu, J. S. Cao and L. F. Ma, Dalton Trans., 2016, 45, 12352-12361; (e) X. L. Wang, X. M. Wu, G. C. Liu, H. Y. Lin and X. Wang, Dalton Trans., 2016, 45, 19341-19350.

11 (a) B. Q. Song, X. L. Wang, J. Liang, Y. T. Zhang, K. Z. Shao and Z. M. Su, CrystEngComm, 2014, 16, 9163-9167; (b) B. Q. Song, X. L. Wang, C. Y. Sun, Y. T. Zhang, X. S. Wu, L. Yang, K. Z. Shao, L. Zhao and Z. M. Su, Dalton Trans., 2015, 44, 13818-13822; (c) G. N. Liu, M. J. Zhang, W. Q. Liu, H. Sun, X. Y. Li, K. Li, C. Z. Ren, Z. W. Zhang and C. C. Li, Dalton Trans., 2015, 44, 18882-18892; (d) J. Zhao, W. W. Dong, Y. P. Wu, Y. N. Wang, C. Wang, D. S. Li and Q. C. Zhang, J. Mater. Chem. A, 2015, 3, 69626969.

12 (a) H. X. Yang, T. F. Liu, M. N. Cao, H. F. Li, S. Y. Gao and R. Cao, Chem. Commun., 2010, 46, 2429-2431; (b) M. C. Das, H. Xu, Z. Y. Wang, G. Srinivas, W. Zhou, Y. F. Yue, V. N. Nesterov, G. D. Qian and B. L. Chen, Chem. Commun., 2011, 47, 11715-11717; (c) L. Liu, D. Q. Wu, B. Zhao, X. Han, J. Wu, H. W. Hou and Y. T. Fan, Dalton Trans., 2015, 44, 1406-1411; (d) N. Hussain and V. K. Bhardwaj, Dalton Trans., 2016, 45, 7697-7707.

13 (a) J. Lu, J. X. Lin, X. L. Zhao and R. Cao, Chem. Commun., 2012, 48, 669-671; (b) Y. Q. Chen, G. R. Li, Y. K. Qu, Y. H. Zhang, K. H. He, Q. Gao and X. H. Bu, Cryst. Growth Des., 2013, 13, 901-907; (c) X. L. Wang, C. H. Gong, J. W. Zhang, G. C. Liu, X. M. Kan and N. Xu, CrystEngComm, 2015, 17, 4179-4189; (d) Y. P. Wu, X. Q. Wu, J. F. Wang, J. Zhao, W. W. Dong, D. S. Li and Q. C. Zhang, Cryst. Growth Des., 2016, 16, 2309-2316.

14 (a) T. Wen, D. X. Zhang, J. Liu, R. Lin and J. Zhang, Chem. Commun., 2013, 49, 5660-5662; (b) T. Wen, D. X. Zhang and J. Zhang, Inorg. Chem., 2013, 52, 12-14; (c) X. T. Zhang, L. M. Fan, W. Zhang, Y. S. Ding, W. L. Fan and X. Zhao, Dalton Trans., 2013, 42, 16562-16568; (d) T. Wen, D. X. Zhang, J. Liu, R. Lin and J. Zhang, CrystEngComm, 2015, 17, 6110-6119; (e) S. Ou, J. P. Zheng, G. Q. Kong and C. D. Wu, Dalton Trans., 2015, 44, 78627869; (f) C. K. Wang, F. F. Xing, Y. L. Bai, Y. M. Zhao, M. X. Li and S. R. Zhu, Cryst. Growth Des., 2016, 16, 22772288.

15 Z. L. Wu, C. H. Wang, B. Zhao, J. Dong, F. Lu, W. H. Wang, W. C. Wang, G. J. Wu, J. Z. Cui and P. Cheng, Angew. Chem., Int. Ed., 2016, 55, 4938-4942.

16 (a) X. X. Lu, Y. H. Luo, Y. S. Liu, W. W. Ma, Y. Xu and H. Zhang, CrystEngComm, 2016, 18, 3650-3654; (b) H. Chen, P. X. Liu, N. Xu, X. Meng, H. N. Wang and Z. Y. Zhou, Dalton Trans., 2016, 45, 13477-13482; (c) L. J. Han, Y. J. Kong, T. J. Yan, L. T. Fan, Q. Zhang, H. J. Zhao and H. G. Zheng, Dalton Trans., 2016, 45, 18566-18571.

17 (a) M. Li, S. Zhao, Y. F. Peng, B. L. Li and H. Y. Li, Dalton Trans., 2013, 42, 9771-9776; (b) Y. F. Peng, S. Zhao, K. Li, L. Liu, B. L. Li and B. Wu, CrystEngComm, 2015, 17, 2544-
2552; (c) L. Liu, Y. F. Peng, X. X. Lv, K. Li, B. L. Li and B. Wu, CrystEngComm, 2016, 18, 2490-2499.

18 (a) K. Li, X. X. Lv, L. L. Shi, L. Liu, B. L. Li and B. Wu, Dalton Trans., 2016, 45, 15078-15088; (b) X. X. Lv, L. L. Shi, K. Li, B. L. Li and H. Y. Li, Chem. Commun., 2017, 53, 1860-1853.

19 B. F. Hoskins, R. Robson and D. A. Slizys, J. Am. Chem. Soc., 1997, 119, 2952-2953.

20 G. M. Sheldrick, Acta Crystallogr., Sect. A: Found. Crystallogr., 2008, 64, 112-122.

21 (a) A. W. Addison, T. N. Rao, J. Reedijk, J. Van Rijn and G. C. Verschoor, J. Chem. Soc., Dalton Trans., 1984, 7, 13491356; (b) B. L. Li, Z. Xu, Z. B. Cao, L. M. Zhu and K. B. Yu, Transition Met. Chem., 1999, 24, 622-627.

22 (a) V. A. Blatov, M. O'Keeffe and D. M. Proserpio, CrystEngComm, 2010, 12, 44-48; (b) E. V. Alexandrov, V. A. Blatov, A. V. Kochetkova and D. M. Proserpio, CrystEngComm, 2011, 13, 3947-3958.

23 (a) J. Zhang, Y. G. Yao and X. H. Bu, Chem. Mater., 2007, 19, 5083-5089; (b) P. David Martin, M. Ronald Supkowski and L. Robert LaDuca, Cryst. Growth Des., 2008, 8, 3518-3520; (c) X. H. Zhou, X. D. Du, G. N. Li, J. L. Zuo and X. Z. You, Cryst. Growth Des., 2009, 9, 4487-4496; (d) Y. Gong, Y. C. Zhou, T. F. Liu, J. Lu, D. M. Proserpio and R. Cao, Chem. Commun., 2011, 47, 5982-5984; (e) S. Z. Zhan, M. Li, X. P. Zhou, J. Ni, X. C. Huang and D. Li, Inorg. Chem., 2011, 50, 8879-8892; $(f)$ W. Q. Kan, J. Yang, Y. Y. Liu and J. F. Ma, Inorg. Chem., 2012, 51, 11266-11278; $(g)$ K. Zhou, F. L. Jiang, L. Chen, M. Y. Wu, S. Q. Zhang, J. Ma and M. C. Hong, Chem. Commun., 2012, 48, 12168-12170; (h) C. Liu, G. H. Cui, K. Y. Zou, J. L. Zhao, X. F. Gou and Z. X. Li, CrystEngComm, 2013, 15, 324-331; (i) X. Q. Yao, J. S. Hu, M. D. Zhang, L. Qin, Y. Z. Li, Z. J. Guo and H. G. Zheng, Cryst. Growth Des., 2013, 13, 3381-3388; (j) M. L. Deng, S. J. Tai, W. Q. Zhang, Y. C. Wang, J. X. Zhu, J. S. Zhang, Y. Ling and Y. M. Zhou, CrystEngComm, 2015, 17, 6023-6029; (k) J. M. Hu, V. A. Blatov, B. Yu, K. V. Heckec and G. H. Cui, Dalton Trans., 2016, 45, 24262429.

24 (a) A. Pintar and J. Levec, Chem. Eng. Sci., 1992, 47, 23952400; (b) A. Corma, H. Garcia and F. X. L. Xamena, Chem. Rev., 2010, 110, 4606-4655; (c) M. N. Chong, B. Jin, C. W. K. Chow and C. Saint, Water Res., 2010, 44, 29973027; (d) J. Kim, C. W. Lee and W. Choi, Environ. Sci. Technol., 2010, 44, 6849-6854; (e) B. Ahmed, E. Limem, A. Abdel-Wahab and B. Nasr, Ind. Eng. Chem. Res., 2011, 50, 6673-6680; $(f)$ N. Inchaurrondo, J. Font, C. P. Ramos and P. Haure, Appl. Catal., B, 2016, 181, 481-494.

25 (a) T. F. Liu, G. H. Cui, C. H. Jiao, C. S. Li and X. C. Deng, Chin. J. Inorg. Chem., 2011, 27, 1417-1422; (b) R. Y. Huang, C. Xue, C. H. Zhu, Z. Q. Wang, H. Xu and X. M. Ren, RSC $A d v .$, 2014, 4, 61200-61209; (c) L. Dobrzanska, G. O. Lloyd, C. Esterhuysen and L. J. Barbour, Angew. Chem., Int. Ed., 2006, 45, 5856-5859; (d) L. Dobrzanska, G. O. Lloyd, H. G. Raubenheimer and L. J. Barbour, J. Am. Chem. Soc., 2005, 127, 13134-13135; (e) L. Dobrzanska, H. G. Raubenheimer and L. J. Barbour, Chem. Commun., 
2005, 5050-5052; $(f)$ T. F. Liu, W. F. Wu, W. G. Zhang and G. H. Cui, Z. Anorg. Allg. Chem., 2011, 637, 148-153; $(g)$ F. J. Liu, D. Sun, H. J. Hao, R. B. Huang and L. S. Zheng, CrystEngComm, 2012, 14, 379-382; (h) F. J. Liu, D. Sun, H. J. Hao, R. B. Huang and L. S. Zheng, J. Mol. Struct., 2012, 1014, 70-73; (i) J. X. Yang, Y. Y. Qin, J. K. Cheng and Y. G. Yao, Cryst. Growth Des., 2014, 14, 1047-1056; (j) L. M. Fan, X. T. Zhang, W. Zhang, Y. S. Ding, W. L. Fan, L. M. Sun and X. Zhao, CrystEngComm, 2014, 16, 2144-
2157; (k) L. M. Fan, X. T. Zhang, W. Zhang, Y. S. Ding, W. L. Fan, L. M. Sun, Y. Pang and X. Zhao, Dalton Trans., 2014, 43, 6701-6710; (l) Z. H. Yan, W. Wang, L. L. Zhang, X. W. Zhang, L. Wang, R. M. Wang and D. F. Sun, RSC $A d v .$, 2015, 5, 16190-16198; (m) Y. C. He, J. Guo, J. Yang, H. Y. Liu, Y. Y. Liu, Q. Y. Zhai, Q. T. Shen and J. F. Ma, Polyhedron, 2015, 99, 156-169; (n) Y. Y. Sun, S. W. Zhao, H. R. Ma, Y. Han, K. Liu and L. Wang, J. Solid State Chem., 2016, 238, 284-290. 